\title{
BGD
}

10, 1051-1081, 2013

\section{Contributions of riverborne inorganic and organic matters to the benthic food web in the East China Sea as inferred from stable isotope ratios}

N. N. Chang ${ }^{1}$, J. C. Shiao ${ }^{1}$, G. C. Gong ${ }^{2}$, S. J. Kao ${ }^{3}$, and C. H. Hsieh ${ }^{1}$

${ }^{1}$ Institute of Oceanography, National Taiwan University, 1, Section 4, Roosevelt Road, Taipei, Taiwan

${ }^{2}$ Institute of Marine Environmental Chemistry and Ecology and Center of Excellence for Marine Bioenvironment and Biotechnology, National Taiwan Ocean University, 2 Pei-Ning Road, Keelung, Taiwan

${ }^{3}$ Research Center for Environmental Changes, Academia Sinica, Taipei, Taiwan

Received: 25 December 2012 - Accepted: 15 January 2013 - Published: 24 January 2013

Correspondence to: J. C. Shiao (jcshiao@ntu.edu.tw)

Published by Copernicus Publications on behalf of the European Geosciences Union.
Riverborne inorganic and organic matters to the benthic food web

N. N. Chang et al.

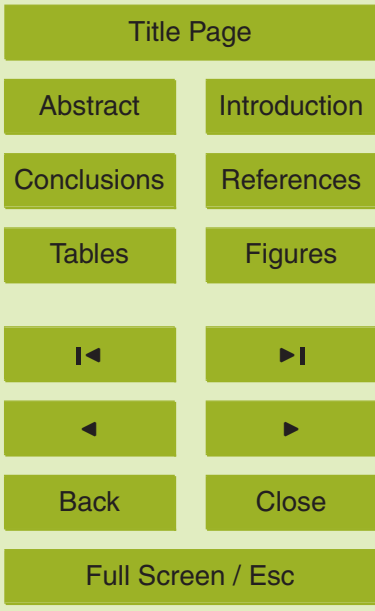

Printer-friendly Version

Interactive Discussion 


\section{Abstract}

Coastal areas adjoining rivers are nourished by both the riverborne nutrients and organic matters. Annually, the East China Sea (ECS) receives large quantities of particulate organic carbon transported from the Changjiang (Yangtze River), as well as 5 nutrients, which have brought about high primary production in the ECS. This study evaluated the respective contributions of terrigenous organic matters (allochthonous food source) and nutrient-induced marine production (autochthonous food source) to the ECS benthic ecosystem by analyzing the stable isotope compositions for zooplankton, benthic crustacea and demersal fish. Zooplankton exhibited consistently higher $\delta{ }^{13} \mathrm{C}$ values (-21.31\%o -19.22\%。) in the inner shelf than in the outer shelf. The $\delta{ }^{13} \mathrm{C}$ signals of fish $(-19.64 \% \sim-13.46 \%$ ) and crustacea $(-18.87 \% \circ \sim-15.00 \%$ o) showed strong reliance on the marine production across the ECS continental shelf, regardless of distance from the shore. Moreover, the benthic crustacea and fish exhibited significantly higher $\delta{ }^{13} \mathrm{C}$ values in the highly productive inshore sites and the $\delta^{13} \mathrm{C}$ values decreased seawards, implying a higher intrusion of atmospheric $\mathrm{CO}_{2}$ and lower photosynthetic fractionation due to algal blooming in the inner shelf. The $\delta^{13} \mathrm{C}$ values of fish also showed significant positive correlations with the concentration of surface chlorophyll $a$ and nitrogen. Riverborne nutrients closely linked marine benthic consumers to the terrestrial watershed and tightly coupled the pelagic and benthic ecosystems in the ECS. The stable isotope compositions of benthic consumers can act as an indicator for pelagic trophic status. The future research combining analyses of stable isotope and community structure may improve assessment on the balance between contribution and risk of phytoplankton blooms.

\section{Introduction}

25 Coastal ecosystems adjacent to large rivers are tightly connected to terrestrial environments through receiving large quantities of freshwater and materials. River inputs

\section{BGD}

10, 1051-1081, 2013

Riverborne inorganic and organic matters to the benthic food web

N. N. Chang et al.

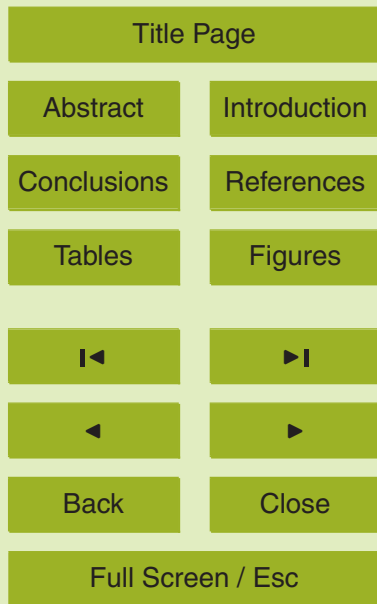

Printer-friendly Version

Interactive Discussion 
of nutrients greatly accelerate the growth of marine primary producers and the nitrogen loadings are positively related to fisheries yields (Nixon et al., 1986). During past decades, anthropogenic activities have driven catastrophic changes in large rivers and their adjacent marginal seas, principally by over-enrichment of nutrients (Nixon, 1995; 5 Diaz, 2001). The global nitrogen and phosphorus fluxes from rivers to coastal oceans have grown more than two- to threefold over the past half century, resulting in more than 760 coastal areas experiencing eutrophication (Howarth et al., 1995; Galloway et al., 2004; Diaz et al., 2011). Nutrient-promoted phytoplankton blooms may nourish the local biota by providing organic matters (Graf, 1992; Nascimento et al., 2008), but 10 may also harm marine ecosystems (Grall and Ghauvaud, 2002). Though eutrophication generally originates in pelagic ecosystems, the effects of increased organic precipitation, accelerated oxygen consumption, and modified habitat structure transcend ecosystem boundaries (Grall and Chauvaud, 2002; Vadeboncoeur et al., 2003). Therefore, both the marine pelagic and benthic communities in the sea areas abutting rivers 15 are susceptible to terrigenous nutrients.

The East China Sea (ECS) has experienced severe eutrophication since the 1960s due to the dramatic increase of nutrient fluxes from the third longest river in the worldthe Changjiang (Yangtze River). Concentrations of dissolved inorganic nitrogen (DIN) and phosphate in the Changjiang water showed more than a five-fold increase between the 1960s and the end of 1990 (Wang, 2006). In the late 1990s more than $1.4 \times 10^{6} \mathrm{tyr}^{-1}$ of inorganic nitrogen were conveyed from the Changjiang into the ECS (Gao and Wang, 2008). The nutrient overload increased the annual occurrence rate of spring algal blooms in the Changjiang estuary and adjacent sea waters from less than 10 times in the 1930s to more than 80 times in 2005 (Zhou et al., 2008). Though the frequent algal blooms are thought to be notorious for their consequent effects on causing bottom-water hypoxia (Chen et al., 2007) and damaging benthic communities (Chang et al., 2012), these blooming materials somehow act as nutritious food for marine secondary producers and probably contribute to higher trophic consumers in the

\section{BGD}

$10,1051-1081,2013$

\section{Riverborne inorganic and organic matters to the benthic food web}

N. N. Chang et al.

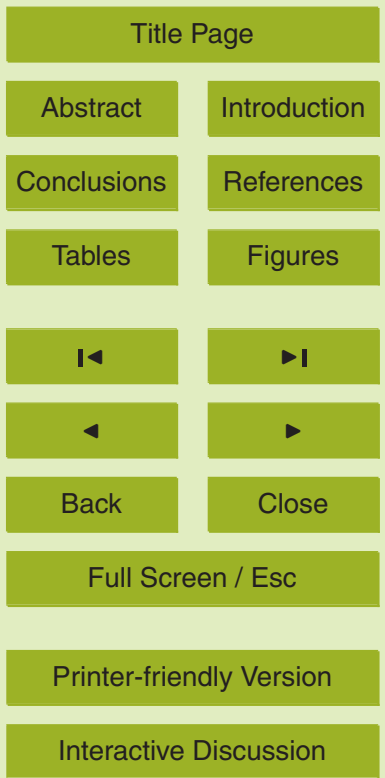


ECS ecosystem, particularly the Changjiang freshwater impacted area (isohaline of salinity 31) in which the highest algal biomass was observed (Gong et al., 2011).

Riverborne organic materials also have potential to nourish the benthic consumers. Terrestrial particulate organic matters (POM) could penetrate marine benthic food webs 5 and even contribute to fishery catches via the ingestion by local macrofauna, such as molluscs, crustaceans and polychaetes (Gearing et al., 1991; Riera and Richard, 1996; Bouillon et al., 2000; Darnuad et al., 2004). Annually, the Changjiang transports ca $4.4 \times 10^{6} \mathrm{t}$ of particulate organic carbon to the adjacent ECS (Dagg et al., 2004; Gao and Wang, 2008), and the transported riverine particles have been observed to 10 travel as far as ca $250 \mathrm{~km}$ from shore (Wu et al., 2003, 2007), thus potentially providing an alternative food source for the benthic consumers in the inner continental shelf. However, it remains unclear whether the riverborne POM would nourish the ECS food webs and how the respective contributions of riverborne POM and nutrient-induced marine production might shift across the extensive ECS continental shelf.

15 Stable carbon and nitrogen isotopes analyses have been successfully applied to clarifying ecosystem trophic structures with multiple food sources (Fry and Sherr, 1984; Minagawa and Wada, 1984; Peterson et al., 1985). The $\delta^{13} \mathrm{C}$ signal of terrestrial POM is generally isotopically lighter by $5-6 \%$ o than in situ marine production and the $\delta^{13} \mathrm{C}$ changes in a predictable way (ca $1 \%$ ) during transmission among trophic levels. Thus, carbon isotope ratios are used to trace terrestrial organic matters in marine ecosystems (Voß and Struck, 1997). In addition, the carbon isotopic composition of primary producers can be further modified in different nutrient regimes (Gearing et al., 1991; Savoye et al., 2003). In highly productive systems, isotopic fractionation of $\mathrm{CO}_{2}$ would be reduced during photosynthesis, thus elevating the $\delta^{13} \mathrm{C}$ values of primary producers and subsequent consumers (Cifuentes et al., 1988). Previous studies suggested that the application of sole isotope composition was probably ambiguous to well determine food sources (Currin et al., 1995). The use of a stable nitrogen isotope could further improve the assessment of organisms' trophic positions because consumers tend to have higher $\delta^{15} \mathrm{~N}$ than their foods by 3 to $4 \%$ (Fry and Sherr, 1984; Minagawa and Wada,

BGD

$10,1051-1081,2013$

\section{Riverborne inorganic and organic matters to the benthic food web}

N. N. Chang et al.

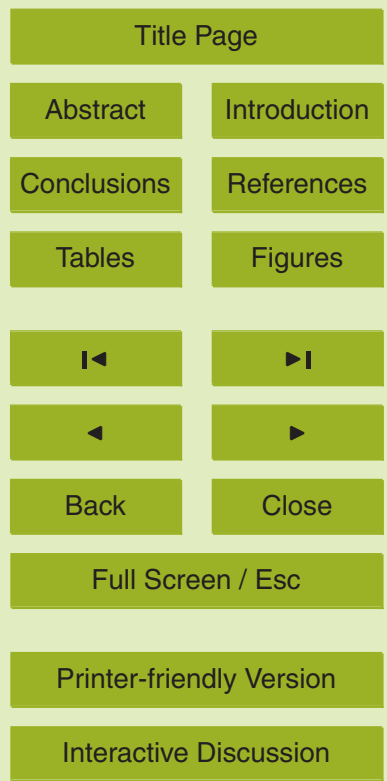


1984; Post, 2002). The dual isotope approach is thought to be reliable for investigating trophic structure (Post, 2002). Therefore, by analyzing the carbon and nitrogen isotope compositions of both pelagic primary consumers and benthic consumers across the shelf, the spatial variations in the food sources for the ECS benthic ecosystems and in 5 the trophic status of the pelagic ecosystems can be clarified.

The present study aims first to evaluate the respective contributions of terrigenous POM (allochthonous) and marine production (autochthonous) to the benthic food web in the ECS. Since the spatial succession of riverborne POM is most concentrated in the Changjiang mouth and rapidly decreases seaward (Wu et al., 2003, 2007; Gong et al.,

2011), we conjecture that the benthic consumers may exhibit a spatial dietary shift from mixed food sources (terrestrial POM and marine production) in the inner shelf to monosource (in situ marine production) in the outer shelf. By analyzing benthic organisms, mainly the demersal fish and crustacea across the extensive ECS continental shelf, we may ascertain how the riverborne nutrients and organic matters contribute to the benthic food webs. Moreover, determining the spatial variability in energy uptake by benthic consumers across a continental shelf with land-based influence may not only improve our understanding of the factors affecting fishery resources in the ECS, but also allow further prediction about the effects of environmental changes on the benthic ecosystem.

\section{Materials and methods}

\subsection{Study sites and sample collection}

Biological samples were collected from the East China Sea (ECS) in July of 2008, 2009, and 2010. The demersal fish and benthic crustacea used for stable isotopic measurements were collected with a bottom beam trawl $(4.7 \mathrm{~m}$ wide, $0.28 \mathrm{~m}$ high, mesh size $2515 \times 15 \mathrm{~mm}^{2}$ ) The bottom trawling surveys were carried out from the inshore to offshore sites. The inshore sites (i.e. $<200 \mathrm{~km}$ from the land) were shallower than $60 \mathrm{~m}$
BGD

10, 1051-1081, 2013

Riverborne inorganic and organic matters to the benthic food web

N. N. Chang et al.

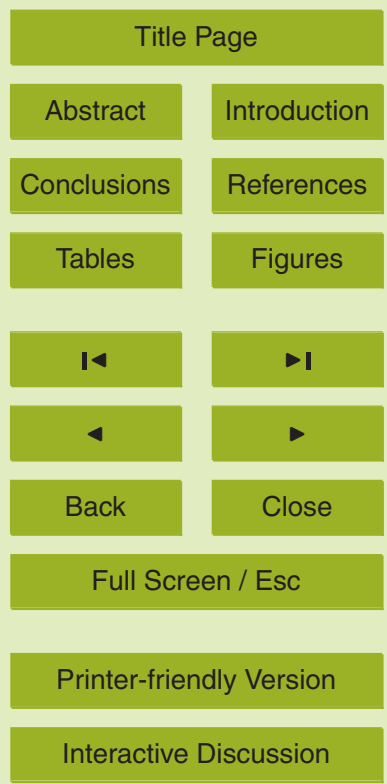


and generally influenced by Changjiang freshwater discharge (Table 1 and Fig. 1). The trawled samples were frozen on board immediately and identified to species in the laboratory. Several common species of demersal fish and crustaceans were selected and three individuals of the selected species were prepared for stable isotopic analyses.

5 For the benthic crustaceans (decapoda and Stomatopoda), only the samples collected from sites A1-A3 in July 2008 were analyzed for stable isotope compositions. In order to distinguish the marine production from terrestrial POM, pelagic primary consumers were analyzed, based on the assumption that marine phytoplankton constitute most of the carbon source for zooplankton (Bouillon et al., 2000). To obtain the marine pri10 mary consumers (zooplankton), a $200 \mu \mathrm{m}$ mesh net was towed in the upper layer of seawater (mainly concentrated at $10 \mathrm{~m}$ depth). The collected samples were further wet-sieved through serial meshes (mesh size $=2000,1000,500$ and $363 \mu \mathrm{m}$ ), and the organisms retaining on the $363 \mu \mathrm{m}$ mesh were used for isotopic analysis. For each sampling period, one inshore site and one offshore site were selected to collect pri15 mary consumers and represent the marine production-based food sources for benthic consumers (Fig. 1).

Hydrological data, including temperature and salinity were measured in situ with a SeaBird Conductivity-Temperature-Depth recorder (SBE 9/11 plus, SeaBird Inc., USA). Water samples for chlorophyll $a$ and nutrients measurements were taken by the CTD rosette assembly (Model1015, General Oceanics Inc., USA). For chlorophyll a analysis, water samples from the sea surface $(<5 \mathrm{~m})$ were filtered through a GF/F filter paper (Whatman, $47 \mathrm{~mm}$ ) and determined fluorometrically. Concentrations of inorganic nitrogen were determined using the analytic methods described in Parsons et al. (1984), Welschmeyer (1994) and Gong et al. (2000).

\subsection{Stable isotopic analysis}

Stable carbon and nitrogen isotopic ratios were determined for the muscle tissues of demersal fish, benthic crustacea and zooplankton. All selected samples were first rinsed with distill water. Muscle samples of fish, shrimp (mantis shrimp included), and

\section{BGD}

10, 1051-1081, 2013

\section{Riverborne inorganic and organic matters to the benthic food web}

N. N. Chang et al.

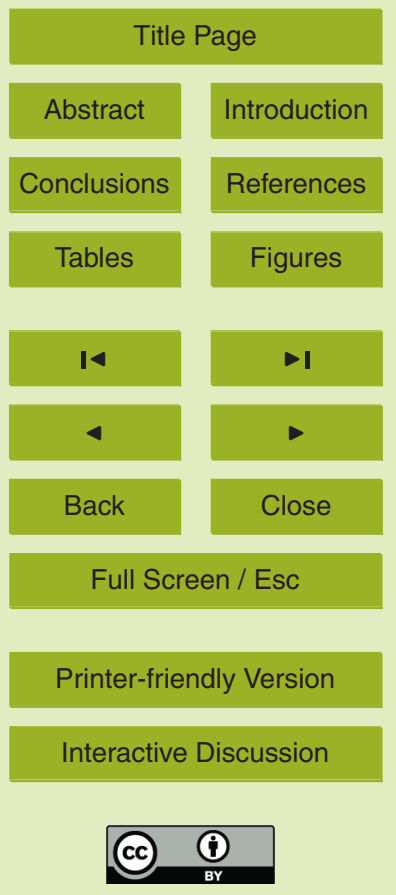


crab were extracted from the upper-dorsal part, trunk, and cheliped to be dried at $60^{\circ} \mathrm{C}$ for a minimum of $24 \mathrm{~h}$. The zooplankton samples were acid-treated with $1 \mathrm{~N}$ $\mathrm{HCl}$ to remove calcium carbonate $\left(\mathrm{CaCO}_{3}\right)$. The acidic treatment does not significantly change the isotopic values of organic matters (Kanaya et al., 2007). All the dried muscle and zooplankton samples were ground into powder and packed into tin capsules. The total content of carbon and nitrogen and their isotopic compositions were determined using an isotope ratio mass spectrometer (Thermo Finnigan Deltaplus Advantage) system connected to an automatic elemental analyzer (Carlo-Erba EA 2100). Analyzed results are expressed by the standard $\delta$ notation as the following: ${ }_{10} \delta X=\left(R_{\text {sample }} / R_{\text {standard }}-1\right) \times 1000(\%)$, where $X$ is ${ }^{13} \mathrm{C}$ or ${ }^{15} \mathrm{~N}$, and $R$ is ${ }^{13} \mathrm{C} /{ }^{12} \mathrm{C}$ for carbon and ${ }^{15} \mathrm{~N} /{ }^{14} \mathrm{~N}$ for nitrogen. Pee dee belemnite (PDB) and atmospheric nitrogen were used as the $\delta^{13} \mathrm{C}$ and $\delta^{15} \mathrm{~N}$ standards, respectively. The US Geological Survey standard \#40 (L-glutamic acid), which has certified $\delta^{13} \mathrm{C}$ value of $-26.24 \%$ and $\delta^{15} \mathrm{~N}$ of $-4.52 \%$ and acetanilide (Merck) with $\delta^{13} \mathrm{C}$ of $-29.76 \%$ and $\delta^{15} \mathrm{~N}$ of $-1.52 \%$ o were used as working standards. The reproducibility of both carbon and nitrogen isotopic measurements is better than $0.15 \%$, which is much smaller than the wide distribution of isotopic compositions in our study.

\subsection{Data analysis}

Since the trophic enrichment factors for $\delta^{15} \mathrm{~N}$ and $\delta^{13} \mathrm{C}$ fluctuate and generally range 20 between 2.5-4.5\%。 (Minagawa and Wada, 1984; Post, 2002) and 1-2\%。 (Wada et al., 1991), respectively, both the maximum and minimum trophic enrichment values were considered to demarcate the lenient ranges of terrestrial POM and marine productionbased food webs on the $\delta^{13} \mathrm{C}$ and $\delta^{15} \mathrm{~N}$ biplot. To investigate the temporal and spatial variability of isotopic signatures, the mean $\delta^{13} \mathrm{C}$ and $\delta^{15} \mathrm{~N}$ values of benthic consumers (fish and crustacea) were compared among sampling sites and years by nonparametric ANOVA (Kruskal-Wallis test) and multiple comparison (Tukey's HSD test) to elucidate the spatial and temporal variation in isotopic compositions. Simple linear

\section{BGD}

10, 1051-1081, 2013

Riverborne inorganic and organic matters to the benthic food web

N. N. Chang et al.

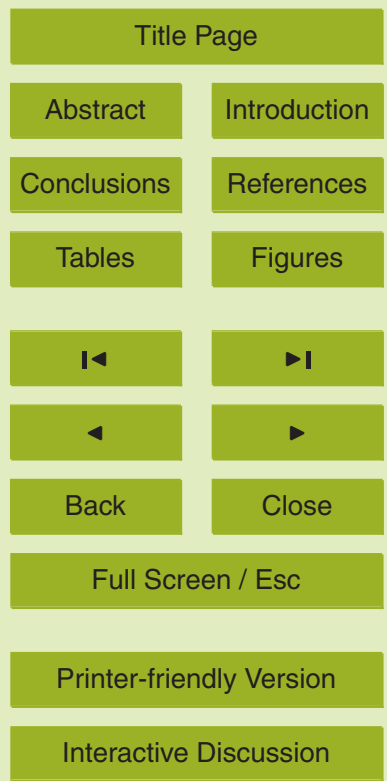


regression was used to determine whether the isotopic values were correlated with environmental characteristics, especially the eutrophic-related variables such as chlorophyll $a$ and nitrogen concentrations.

\section{Results}

\section{$5 \quad 3.1$ Environmental characteristics across the ECS continental shelf}

The three-year sampling in the ECS continental shelf of environmental characteristics, i.e. salinity, temperature, nutrients, and chlorophyll a concentrations exhibited pronounced gradient variations between inshore and offshore areas (Table 1). Concentrations of DIN decreased greatly from the inner shelf to the outer shelf and the concentrations at the inshore sites (O1, A1, B1 and $\mathrm{C} 1)$ were about tenfold higher than the offshore areas in July 2008 and 2010 . The inner shelf was characterized as highly productive, with chlorophyll a concentrations generally higher than $2 \mathrm{mg} \mathrm{m}^{-3}$ at most inshore sites. Temporally, surface water salinity was lower and chlorophyll a concentrations higher in July 2010 than in 2008 and 2009, due to the influence of the Changjiang flood during the summer of 2010 (Gong et al., 2011). Moreover, the increase in chlorophyll a concentration was not restricted to the inner shelf but also extended to the middle and outer shelf. In contrast, overall lower concentrations of DIN and chlorophyll a were observed in July 2009.

\subsection{Isotopic signatures of zooplankton and benthic crustacea}

20

Inshore zooplankton samples exhibited more enriched ${ }^{13} \mathrm{C} \quad\left(\delta^{13} \mathrm{C}=-21.31 \%\right.$ 。 $\sim-19.22 \%$ ) and relatively depleted signatures occurred in the outer shelf $\left(\delta^{13} \mathrm{C}=-21.79 \%\right.$ $~-20.13 \%$; Table 2). The spatial variation of $\delta^{13} \mathrm{C}$ was minor in July 2009 with a difference less than $0.5 \%$ o between inshore and offshore sites. The $\delta{ }^{13} \mathrm{C}$ values of offshore zooplankton were higher in July 2010 than in 2008 and 2009. The isotopic compositions of zooplankton were assumed to represent the in situ marine

1058

\section{BGD}

10, 1051-1081, 2013

Riverborne inorganic and organic matters to the benthic food web

N. N. Chang et al.

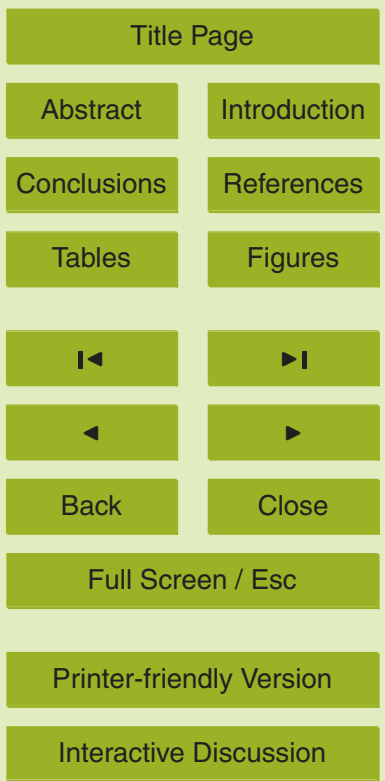


production. The range of marine production and terrestrial POM carbon contributed to consumer food webs was demarcated on $\delta^{13} \mathrm{C}$ and $\delta{ }^{15} \mathrm{~N}$ biplots (Fig. 2). In total, the isotopic compositions of 51 benthic crustacean samples belonging to 12 species of decapoda and stomatopoda were analyzed. The crustacea showed a wide range 5 of $\delta{ }^{13} \mathrm{C}(-18.87 \% \circ \sim-15.00 \%$ ) and samples collected at site A1 (mean $=-16.07 \%$ ) were significantly higher than that at sites A2 and A3 $(p<0.0001$; Table 3$) . \delta^{15} \mathrm{~N}$ of crustacea varied from 8.83 to $11.78 \%$ and did not differ significantly among sites. For six common crustacean species, plots of $\delta^{13} \mathrm{C}$ and $\delta^{15} \mathrm{~N}$ values against the distance from shore showed that all of the species exhibited the highest $\delta^{13} \mathrm{C}$ in the inner shelf 10 (site A1) and the spatial variation reached $2.07 \%$ ofor Charybdis bimaculata (Fig. 3a). The $\delta^{15} \mathrm{~N}$ values for crustacean species had no consistent spatial trend, yet the interspecific variation generally decreased seawards (Fig. 3b).

\subsection{Isotopic signature of fish communities}

A total of 41 species of demersal fishes collected from 15 trawls in July 2008, 2009 15 and 2010 were analyzed for their stable isotopic compositions. Overall, the $\delta^{13} \mathrm{C}$ of fish ranged from $-19.22 \%$ o to $-13.72 \%$ ond the $\delta{ }^{15} \mathrm{~N}$ ranged between $7.93 \%$ and $13.99 \%$ (Table S1). The isotopic composition of most fish located within the schematic range of marine production indicates that they fed on zooplankton from either inshore or offshore locations in all sampling years (Fig. 4). Few individuals showed a probability of 20 incorporating terrestrial POM. The mean $\delta^{13} \mathrm{C}$ and $\delta{ }^{15} \mathrm{~N}$ values of demersal fish varied from $-18.23 \%$ o to $-14.31 \%$ and $8.76 \%$ o to $11.82 \%$, respectively, among sampling sites (Table 3). For each sampling year, the demersal fish at inshore sites exhibited significantly higher $\delta^{13} \mathrm{C}$ values than at offshore sites ( $p \leq 0.0001$; Table 3$)$. The highest $\delta^{13} \mathrm{C}$ values occurred at the inshore sites B1 (2008) and C1 (2009 and 2010). Mean ${ }_{25} \delta^{15} \mathrm{~N}$ values of demersal fish also differed significantly among sampling sites each year $(p<0.0001)$. Slightly but significantly lower $\delta^{15} \mathrm{~N}$ values occurred in fish inhbited in the inner shelf and higher values in the middle to outer shelf. Temporally, fish collected in July 2008 and 2010 showed larger variation in $\delta^{13} \mathrm{C}$ values and generally more 1059

\section{BGD}

$10,1051-1081,2013$

Riverborne inorganic and organic matters to the benthic food web

N. N. Chang et al.

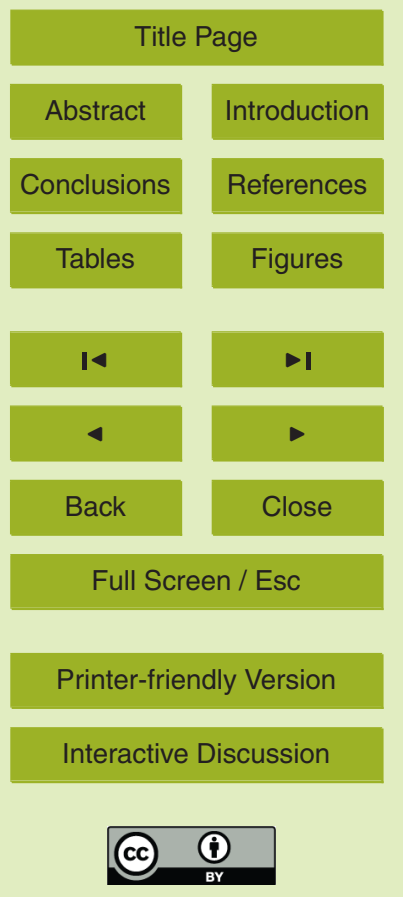


enriched ${ }^{13} \mathrm{C}$. In contrast, samples in July 2009 exhibited smaller isotopic variation and more negative $\delta^{13} \mathrm{C}$ values (Fig. 4). Particularly, fish sampled at sites $\mathrm{A} 1$ and A2 exhibited significantly higher $\delta^{13} \mathrm{C}$ in July 2010 than in other years (chi-sq $=44.15$ and 21.09, respectively; $p<0.0001$ ), yet fish $\delta^{13} \mathrm{C}$ at site $\mathrm{A} 3$ did not differ significantly 5 among years (chi-sq $=1.9 ; p=0.387$ ).

\subsection{Spatiotemporal variations in $\delta^{13} \mathrm{C}$ and $\delta^{15} \mathrm{~N}$ of fish species}

For several common species, including Amblychaeturichthys hexanema, Apogon lineatus, Antennarius striatus, Cynoglossus interruptus, Champsodon snyderi, Chelidonichthys spinosus, Lepidotrigla alata, Pennahia argentata and Pleuronichthys cor10 nutus, $\delta^{13} \mathrm{C}$ and $\delta^{15} \mathrm{~N}$ isotopic values were compared among study sites (generally more than three) and among sampling years (generally more than two years). The $\delta^{13} \mathrm{C}$ of most species showed the highest values at the inshore area $(<200 \mathrm{~km}$ from shore), and gradually decreased with the distance from the shore, especially the benthic fishes $-A$. hexanema, $A$. striatus, $C$. spinosus, and $L$. alata (Fig. 5). The variation 15 in $\delta^{13} \mathrm{C}\left(\Delta \delta^{13} \mathrm{C}\right)$ from the inshore to offshore areas reached $3.66 \%$ for $C$. spinosus, $2.45 \%$ o for $P$. argentata, and $2.77 \%$ o for $L$. alata in July 2008, 2009, and 2010, respectively. Other fish species, including $C$. snyderi and $A$. lineatus, exhibited smaller spatial variation in $\delta{ }^{13} \mathrm{C}$ values. The $\delta{ }^{13} \mathrm{C}$ of fishes was found highest in July 2010 and lowest in July 2009. The seaward decreasing trend of $\delta^{13} \mathrm{C}$ was less pronounced in July 2009. Conversely, the $\delta^{15} \mathrm{~N}$ of demersal fishes increased from offshore to inshore sites (Fig. 6). For most species, the lowest $\delta^{15} \mathrm{~N}$ values occurred in the inshore areas. The sciaenid $P$. argentata demonstrated large spatial variations in $\delta^{15} \mathrm{~N}$ between the inshore and offshore sites in $2008\left(\Delta \delta^{15} \mathrm{~N}=4.19 \%\right.$ ) and $2009\left(\Delta \delta^{15} \mathrm{~N}=2.31 \%\right.$ ); the $\delta{ }^{15} \mathrm{~N}$ variation of $A$. hexanema reached $1.80 \%$ in 2010 . Nevertheless, a small number
BGD

10, 1051-1081, 2013

\section{Riverborne inorganic and organic matters to the benthic food web \\ N. N. Chang et al.}

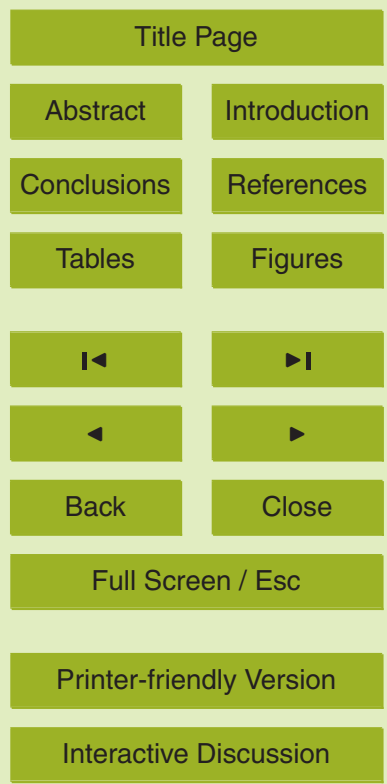




\subsection{Relationships between environmental characters and isotopic composition}

Linear regressions of fish $\delta^{13} \mathrm{C}$ on chlorophyll $a$ and DIN concentrations from the three sample years were significantly positive $\left(r^{2}=0.82\right.$ and 0.74 , respectively; $p<0.0001$, Fig. 7a, b) while fish $\delta^{15} \mathrm{~N}$ negatively correlated to these two variables, with the $p$ val5 ues $=0.047$ and 0.003 , respectively (Fig. 7c, d). Highly eutrophic conditions and corresponding high values of $\delta^{13} \mathrm{C}$ mainly occurred in July 2008 and 2010, which profoundly influenced the regression significance.

\section{Discussions}

\subsection{Food source for the benthic ecosystem}

10 In the East China Sea, most fish exhibited higher dependence on in situ marine production, which is characterized as higher $\delta^{13} \mathrm{C}$ values of $-21.79 \% \sim-19.22 \%$ o than on terrestrial particulate organic matters (POM). Although river inputs of terrestrial origin POM may potentially contribute to coastal fishery productivity, the present study found very few fish obtained their energy from terrestrial POM (average $\delta^{13} \mathrm{C}=-25.6 \%$; Wu 15 et al., 2007). The exploitation of terrestrial POM by estuarine macroinvertebrates is regarded to be an important pathway for nourishing marine benthic food webs (Riera and Richard, 1996; Bouillon et al., 2000; Darnuad et al., 2004). For instance, the sole (Solea solea) fishery yield in the Gulf of Lion (NW Mediterranean) was closely related to the density of deposit-feeding polychaetes, which mainly fed on the terrigenous POM derived from the Rhone River (Darnaude et al., 2004). However, the terrestrial material is rich with cellulose and lignin that are refractory and poorly digested by most aquatic consumers, thus restricting its contribution to higher consumers in the estuaries and coastal areas (Deegan and Garritt, 1997; Cividanes et al., 2002). Furthermore, the terrestrial detritus loses energy through the detrital food chain and

\section{BGD}

10, 1051-1081, 2013

Riverborne inorganic and organic matters to the benthic food web

N. N. Chang et al.

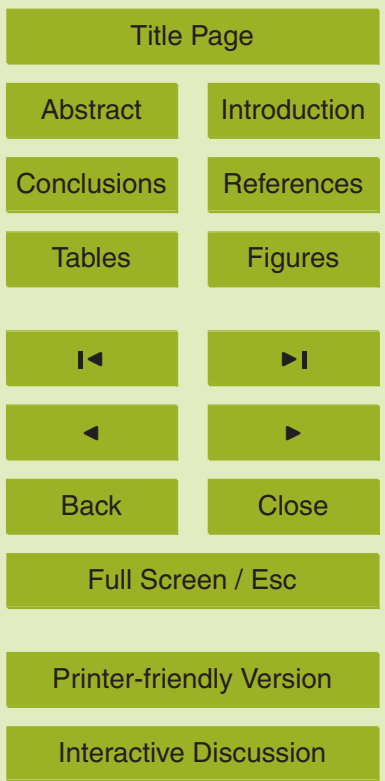


source for fishes (Peterson and Howarth, 1987). Although the terrestrial POM transported by the Changjiang was estimated to contribute $>70 \%$ of the total POM within a distance of $<100 \mathrm{~km}$ from the river mouth and about $50 \%$ at a distance of $150 \mathrm{~km}$ (Wu et al., 2003), benthic communities in the ECS rarely consumed the terrestrial POM 5 at any distance off the Changjiang Estuary. The more depleted carbon isotopic ratio of the inshore sedimentary organic matters $\left(\delta^{13} \mathrm{C}<-21.5 \%\right.$; Kao et al., 2003) is also evidence for the residual terrestrial POM in the shelf sediments. Conversely, marine production is a more nutritious energy source for estuarine and marine consumers (Antonio et al., 2012). Marine primary production can either closely correlate to the survival 10 and growth rates of larval fish and their recruitment or energize benthic juvenile and adult fish through the food web. Primary production across the ECS continental shelf is generally high, particularly in the northwestern half of the shelf where the annual primary production can reach $155 \mathrm{~g} \mathrm{C} \mathrm{m}^{-2}$ (Gong et al., 2003). It can therefore be inferred that phytoplankton production in the ECS plays a more important role in sustaining the 15 local benthic food web when compared with other relatively oligotrophic seas such as the Mediterranean Sea.

\subsection{Isotopic variations in benthic consumers}

Even though the in situ marine production was the main food source for benthic communities, large isotopic variations in fish and crustacea occurred among sampling sites. 20 The $\delta^{13} \mathrm{C}$ values of these benthic consumers declined with seaward distance, with the highest values at the inshore sampling sites ( $<200 \mathrm{~km}$ from the shore). This seaward decline may be caused by higher trophic levels of fish in the inner shelf or more enriched isotopic signatures at the bottom of the inshore food web (Vander Zanden and Vadeboncoeur, 2002; Gerdeaux and Perga, 2006). Changes in trophic levels and 25 trophic links are widely assessed from stable nitrogen isotope $\left(\delta^{15} \mathrm{~N}\right)$. The conventional trophic enrichment from prey to predator is about $3.4 \%$ for $\delta^{15} \mathrm{~N}$ and less than $1 \%$ for $\delta^{13} \mathrm{C}$ (Fry and Sherr, 1984; Minagawa and Wada, 1984; Peterson et al., 1985; Post, 2002). However, this study found that spatial variations in $\delta^{15} \mathrm{~N}$ for benthic consumers

\section{BGD}

10, 1051-1081, 2013

\section{Riverborne inorganic and organic matters to the benthic food web}

N. N. Chang et al.

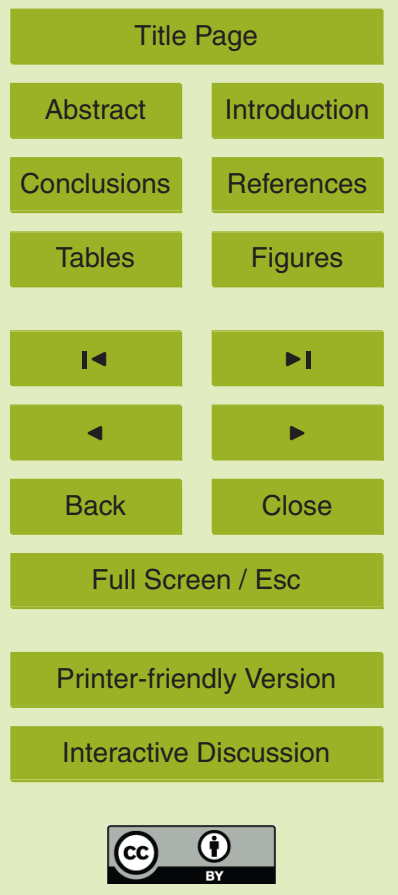


were even less than in $\delta^{13} \mathrm{C}$, the contrary of previous observations. Moreover, the $\delta^{13} \mathrm{C}$ and $\delta^{15} \mathrm{~N}$ values of fish showed distinctly opposite spatial trends across the shelf. This uncoupling of $\delta^{13} \mathrm{C}$ and $\delta^{15} \mathrm{~N}$ trends across the shelf implied other factors affecting the isotopic variability of the demersal fish rather than conventional trophic enrichment.

5 The spatial trend of $\delta^{13} \mathrm{C}$ for crustacea was similar to that for fish, perhaps caused by isotopic variation at even lower trophic levels.

The disparity between $\delta^{13} \mathrm{C}$ values of inshore and offshore zooplankton is evidence for isotopic variation in marine primary production in the ECS. Although POM $\delta{ }^{13} \mathrm{C}$ might became more depleted with increasing depth (Tan and Strain, 1979), more re10 cent large scale surveys demonstrated no difference between sediment $\delta^{13} \mathrm{C}$ and surface POM $\delta{ }^{13} \mathrm{C}$ at various depths ranging from a few to a thousand meters (Naidu et al., 2000; Davenport and Bax, 2002). In fact, $\delta^{13} \mathrm{C}$ signatures of primary producer in the surface water depend on both the photosynthetic fractionation and the $\delta^{13} \mathrm{C}$ of DIC sources (Raven et al., 1994). In the summer period, the ECS shelf acts as 15 a significant $\mathrm{CO}_{2}$ sink due to the phytoplankton bloom in the inner shelf which is influenced by Changjiang freshwater (Chou et al., 2009). The DIC originated from the solution of atmospheric $\mathrm{CO}_{2}\left(\delta^{13} \mathrm{C}=-8 \% \sim-7 \%\right.$ ) is characterized as a relatively ${ }^{13} \mathrm{C}$-enriched source for the DIC pool (Schindler et al., 1997). During phytoplankton blooms, the increasing demand for $\mathrm{CO}_{2}$ of algae causes a higher proportion of ${ }^{13} \mathrm{C}$ in the remaining DIC pool and then the photosynthetic fractionation rate between DIC and organic matters further decreases (Gerdeaux and Perga, 2006). The combined effects of increased availability of atmospheric $\mathrm{CO}_{2}$ and decreased photosynthetic fractionation can result in higher $\delta^{13} \mathrm{C}$ signatures for pelagic primary producers (Schindler et al., 1997; Gerdeaux and Perga, 2006). In this study, the sampling sites that were characterized as high $\delta^{13} \mathrm{C}$ for fish muscle (i.e. O1, A1, B1 and $\mathrm{C} 1$ ) corresponded exactly to the Changjiang plume area where algal blooms occurred frequently during May and June (Tang et al., 2006; Wang and Wu, 2009). In particular, large algal blooms over wide areas were observed in July 2010 - the flooding period of the Changjiang when the average rate of carbon fixation was about 3 times higher than that

BGD

$10,1051-1081,2013$

Riverborne inorganic and organic matters to the benthic food web

N. N. Chang et al.

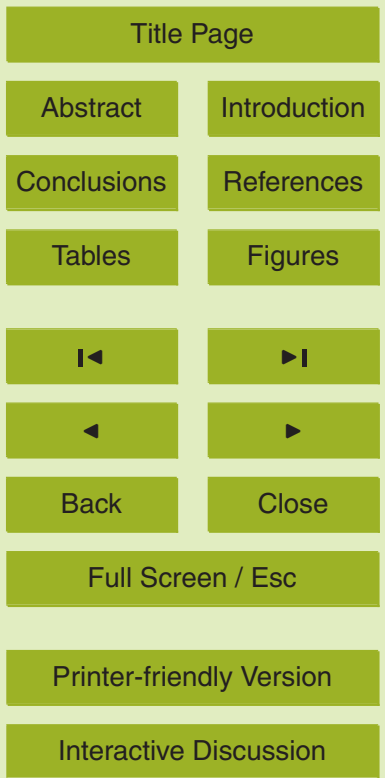


of the non-flood period (Gong et al., 2011). The enhanced carbon fixation could be the main source for the overall elevated $\delta^{13} \mathrm{C}$ values for inshore and offshore zooplankton $\left(\delta^{13} \mathrm{C}=-20.13 \% \circ \sim-19.96 \%\right.$ ) and fish $\left(\delta^{13} \mathrm{C}=-18.67 \%\right.$ $~-13.72 \%$ ) in July 2010. The flood-induced algal bloom was largely dominated by diatoms (Gong et al., 2011), 5 which are characterized as a ${ }^{13} \mathrm{C}$-enriched marine food source (Fry and Wainright, 1991). Therefore, a reasonable inference is that the isotopically enriched benthic consumers in the inner shelf originated from the spring algal bloom. In contrast, less freshwater influence represented by more depleted $\delta^{13} \mathrm{C}$ of both zooplankton and benthic consumers was observed in July 2009 when the Changjiang discharge was less than $1060 \%$ of that in July 2010 (Gong et al., 2011) and reflected a lower degree of algal blooming.

\subsection{Application of isotopic analysis for benthic consumers}

The $\delta^{13} \mathrm{C}$ of benthic consumers in the ECS could be a reliable indicator of the eutrophic status of pelagic ecosystems as it is closely coupled with pelagic primary production. 15 In addition, the relatively slow turnover rate of fish tissue could provide integrated information about their diet (Vander Zanden and Vadeboncoeur, 2002). Previously, strong isotopic evidence for eutrophication may come from analyzing in situ POM (Savoye et al., 2003; Tamelander et al., 2009). For instance, the $\delta^{13} \mathrm{C}$ of water column POM was elevated by up to $8 \%$ (average $=3 \%$ ) in the late-bloom stage of an Arctic ma20 rine ecosystem (Tamelander et al., 2009). Nonetheless, it might be controversial to determine potential food availability for benthic community by directly measuring the $\delta^{13} \mathrm{C}$ of in situ primary producers because of the large variability in the $\delta^{13} \mathrm{C}$ of POM (Vadeboncoeur and Jeppesen, 2003) In systems with multiple carbon sources, such as estuarine and coastal ecosystems, the $\delta^{13} \mathrm{C}$ of in situ POM may reflect the mixing 25 signals of both marine and terrigenous primary production. The isotopic signatures of POM and sedimentary organic materials across the ECS continental shelf have consistently demonstrated low $\delta{ }^{13} \mathrm{C}$ values in the estuarine and inshore areas, implying influence of terrestrial POM (Kao et al., 2003; Wu et al., 2003; Zhu et al., 2008), yet

\section{BGD}

10, 1051-1081, 2013

Riverborne inorganic and organic matters to the benthic food web

N. N. Chang et al.

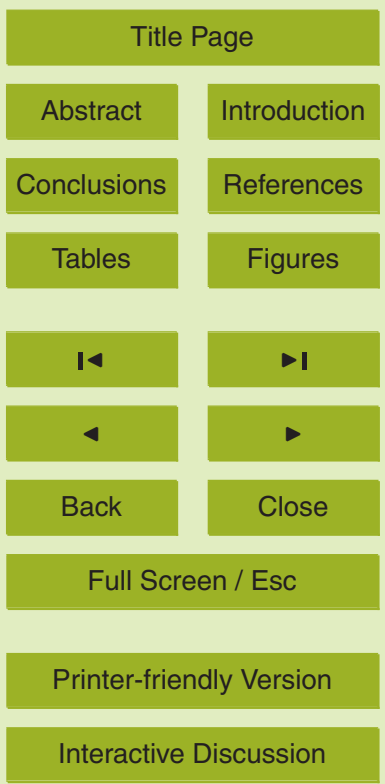


this study on zooplankton and benthic consumers displayed the highest $\delta^{13} \mathrm{C}$ values in the estuarine and inshore areas. This study demonstrated gradual enrichment of crustacea and demersal fish $\delta^{13} \mathrm{C}$ from oligotrophic offshore to eutrophic inshore sites (spatial variation in $\delta^{13} \mathrm{C}=1 \%$ o to $>3 \%$ ). Given that the marine consumers selectively 5 incorporate more nutritious marine production, the POM in the water column and sediment might represent very limited food source for local consumers.

\subsection{Potential impediment to contribution of marine production}

This study has demonstrated that marine primary production was the major food source for the ECS benthic ecosystem and the bloom materials may be incorporated into the 10 benthos. However, the findings do not imply overall positive relationships between algal blooms and the local biota. The macrofaunal species richness has been found to drop and the density of opportunistic species to rise in ecosystems that are subject to increased organic loadings owing to the negative influence of siltation, habitat modification, and oxygen depletion (Pearson and Rosenberg, 1978; Grall and Chauvaud, 2002) In particular, hypoxia has damaged worldwide coastal ecosystems (except Antarctica) and caused losses of habitat, prey availability and demersal fishery (Pihl, 1994; Diaz, 2001; Powers et al., 2005). Since the 1960s, the Changjiang estuary and adjacent waters have suffered from severe seasonal hypoxia, which was estimated to extend over $12000 \mathrm{~km}^{2}$ in the recent one decade (Chen et al., 2007) so that the contribution of phytodetritus settling in the hypoxic areas to fishery resources may be very limited. In conclusion, riverborne nutrients play an important role in linking the trophic structure of marine benthic ecosystem to the terrestrial watershed. The isotopic compositions of benthic consumers provide useful insights into the major carbon sources nourishing the benthic ecosystem and eutrophic status of marine pelagic ecosystem.

25 These results indicate a strong coupling between benthic and pelagic ecosystems in the eutrophic marine environment. Finally, the future research combining analyses of
BGD

10, 1051-1081, 2013

Riverborne inorganic and organic matters to the benthic food web

N. N. Chang et al.

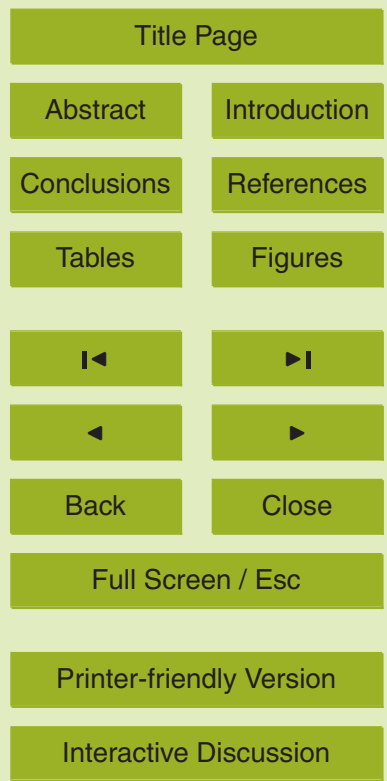


stable isotope and community structure may shade more light on the balance between contribution and risk of phytoplankton blooms.

\section{Supplementary material related to this article is available online at: http://www.biogeosciences-discuss.net/10/1051/2013/ 5 bgd-10-1051-2013-supplement.pdf.}

Acknowledgements. This investigation was funded by the National Science Council (NSC), Taiwan under Grant no. NSC 98-2611-M-002-004-MY3. We are grateful for the constructive comments on the manuscript by Brian Jessop. We also thank Wei-Hsuan Teng, Pei-Chi Ho, Wei-Ju Chien and the crew of the Ocean Researcher I for laboratory and field assistance.

\section{References}

Antonio. E. S., Kasai, A., Ueno, M., Ishihi, Y., Yokoyama, H., and Yamashita, Y.: Spatial-temporal feeding dynamics of benthic communities in an estuary-marine gradient, Estuar. Coast. Shelf Sci., 112, 86-97, 2012.

Bouillon, S., Chandra Mohan, P., Sreenivas, N., and Dehairs, F.: Sources of suspended organic matter and selective feeding by zooplankton in an estuarine mangrove ecosystem as traced by stable isotopes, Mar. Ecol. Prog. Ser., 208, 79-92, 2000.

Caddy, J. F. and Bakun, A.: A tentative classification of coastal marine ecosystems based on dominant processes of nutrient supply, Ocean Coast. Manage., 23, 201-211, 1994.

Chang, N. N., Shiao, J. C., and Gong, G, C.: Diversity of demersal fish in the East China Sea: implication of eutrophication and fishery, Cont. Shelf Res., 47, 42-54, 2012.

Chen, C. C., Gong, G. C., and Shiah, F. K.: Hypoxia in the East China Sea: one of the largest coastal low-oxygen areas in the world, Mar. Environ. Res., 64, 399-408, 2007.

Chou, W. C., Gong, G. C., Sheu, D. D., Jan, S., Hung, C. C., and Chen, C. C.: Reconciling the paradox that the heterotrophic waters of the East China Sea shelf act as a significant doi:10.1029/2009GL038475, 2009.

BGD

10, 1051-1081, 2013

Riverborne inorganic and organic matters to the benthic food web

N. N. Chang et al.

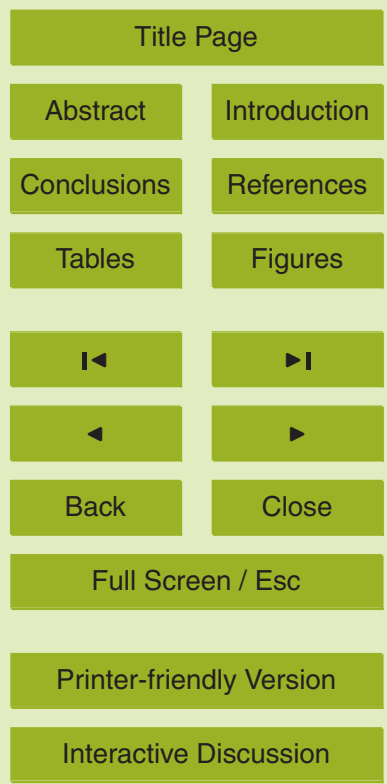


Cifuentes, L. A., Sharp, J. H., and Fogel, M. L.: Stable carbon and nitrogen isotope biogeochemistry in the Delaware estuary, Limnol. Oceanogr., 33, 1102-1115, 1988.

Cividanes, S., Incera, M., and Lopez, J.: Temporal variability in the biochemical composition of sedimentary organic matter in an intertidal flat of the Galician coast (NW Spain), Oceanolog5 ica Acta, 25, 1-12, 2002.

Currin, C. A., Newell, S. Y., and Paerl, H. W.: The role of standing dead Spartina alterniflora and benthic microalgae in salt marsh food webs: considerations based on multiple stable analysis, Mar. Ecol. Prog. Ser., 121, 99-116, 1995.

Dagg, M., Benner, R., Lohrenz, S., and Lawrence, D.: Transformation of dissolved and particulate materials on continental shelves influenced by large rivers: plume processes, Cont. Shelf Res., 24, 833-858, 2004.

Darnaude, A. M., Salen-Picard, C., Polunin, N. V. C., and Harmelin-Vivien, M. L.: Trophodynamic linkage between river runoff and coastal fishery yield elucidated by stable isotope data in the Gulf of Lions (NW Mediterranean), Oecologia, 138, 325-332, 2004.

Davenport, S. R. and Bax, N. J.: A trophic study of a marine ecosystem off southeastern Australia using stable isotopes of carbon and nitrogen, Can. J. Fish. Aquat. Sci., 59, 514-530, 2002.

Deegan, L. A. and Garritt, R. H.: Evidence for spatial variability in estuarine food webs, Mar. Ecol. Prog. Ser., 147, 31-47, 1997.

20 Diaz, R. J.: Overview of Hypoxia around the World, J. Environ. Qual., 30, 275-281, 2001.

Diaz, R., Selman, M., and Chique, C.: Eutrophication and hypoxia: nutrient pollution in coastal waters, global eutrophic and hypoxic coastal systems, World Resources Institute, 2011.

Fry, B., and Sherr, E. B.: $\delta^{13} \mathrm{C}$ measurements as indicators of carbon flow in marine and freshwater ecosystems, Cont. Mar. Sci., 27, 13-47, 1984.

25 Fry, B. and Wainright, S. C.: Diatom sources of ${ }^{13} \mathrm{C}$-rich carbon in marine food webs, Mar. Ecol. Prog. Ser., 76, 149-157, 1991.

Grall, J. and Chauvaud, L.: Marine eutrophication and benthos: the need for new approaches and concepts, Global Change Biol., 8, 813-830, 2002.

Galloway, J. N., Dentener, F. J., Capone, D. G., Boyer, E. W., Howarth, R. W., Seitzinger, S. P., Asner, G. P., Cleveland, C. C., Green, P. A., Holland, E. A., Karl, D. M., Michaels, A. F., Porter, J. H., Townsend, A. R., and Vöosmarty, C. J.: Nitrogen cycles: past, present, and future, Biogeochemistry, 70, 153-226, 2004.

\section{BGD}

10, 1051-1081, 2013

\section{Riverborne inorganic and organic matters to the benthic food web}

N. N. Chang et al.

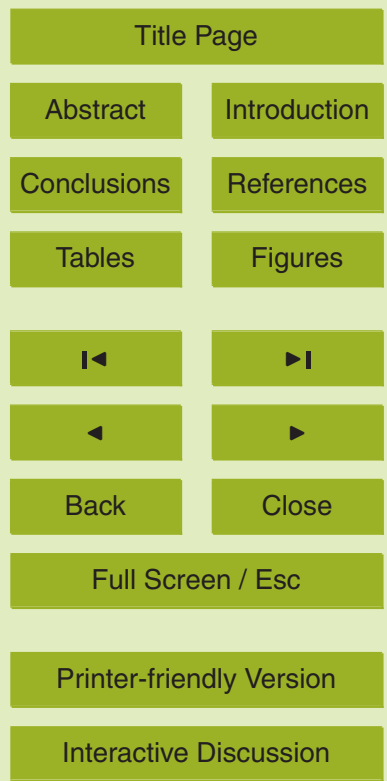


Gao, S. and Wang, Y. P.: Changes in material fluxes from the Changjiang River and their implications on the adjoining continental shelf ecosystem, Cont. Shelf Res., 28, 1490-1500, 2008.

Gearing, P. J., Gearing, J. N., Maughan, J. T., and Oviatt, C. A.: Isotopic distribution of carbon 5 from sewage sludge and eutrophication in the sediments and food web of estuarine ecosystems, Environ. Sci. Technol., 25, 295-301, 1991.

Gerdeaux, D. and Perga, M.-E.: Changes in whitefish scales $\delta^{13} \mathrm{C}$ during eutrophication and reoligophication of subalpine lakes, Limnol. Oceanogr., 51, 772-780, 2006.

Gong, G. C., Shiah, F. K., Liu, K. K., Wen, Y. H., and Liang, M. H.: Spatial and temporal variation of chlorophyll $a$, primary productivity and chemical hydrography in the southern East China Sea, Cont. Shelf Res., 20, 411-436, 2000.

Gong, G. C., Wen, W. H., Wang, B. W., and Liu, G. J.: Seasonal variation of chlorophyll a concentration, primary production and environmental conditions in the subtropical East China Sea, Deep Sea Res. Part II, 50, 1219-1236, 2003.

15 Gong, G. C., Liu, K. K., Chiang, K. P., Hsiung, T. M., Chang, J., Chen, C. C., Hung, C. C., Chou, W. C., Chung, C. C., Chen, H. Y., Shiah, F. K., Tsai, A. Y., Hsieh, C. H., Shiao, J. C., Tseng, C. M., Hsu, S. C., Lee, H. J., Lee, M. A., Lin, I. I., and Tsai, F.: Yangtze River floods enhance coastal ocean phytoplankton biomass and potential fish production, Geophys. Res. Lett., 38, L13603, doi:10.1029/2011GL047519, 2011.

20 Graf, G.: Benthic-pelagic coupling - a benthic view, Oceanogr. Mar. Biol., 30, 149-190, 1992.

Grall, J. and Chauvaud, L.: Marine eutrophication and benthos: the need for new approaches and concepts, Global Change Biol., 8, 813-830, 2002.

Howarth, R. W., Jensen, H., Marino, R., and Postma, H.: Transport to and processing of phosphorus in near-shore and oceanic waters, in: Phosphorus in the Global Environment: Transfers, Cycles, and Management, edited by: Tiessen, H., John Wiley and Sons, Chichester, UK, 1995.

Kanaya, G., Takagi, S., Nobata, E., and Kikuchi, E.: Spatial dietary shift of macrozoobenthos in a brackish lagoon revealed by carbon and nitrogen stable isotope ratios, Mar. Ecol. Prog. Ser., 345, 117-127, 2007.

so Kao, S. J., Lin, F. J., and Liu, K. K.: Organic carbon and nitrogen contents and their isotopic compositions in surficial sediments from the East China Sea shelf and the southern Okinawa Trough, Deep-Sea Res. Pt. II, 50, 1203-1217, 2003.

\section{BGD}

10, 1051-1081, 2013

\section{Riverborne inorganic and organic matters to the benthic food web}

N. N. Chang et al.

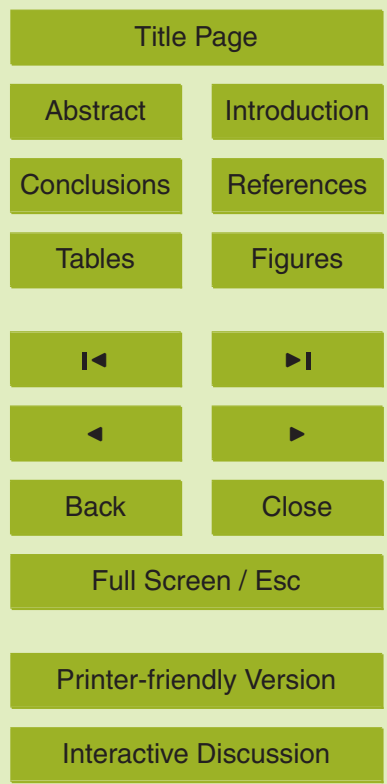


Minagawa, M. and Wada, E.: Stepwise enrichment of $\delta^{15} \mathrm{~N}$ along food chains: further evidence and the relation between $\delta^{15} \mathrm{~N}$ and animal age, Geochim. Cosmochim. Ac., 48, 1135-1140, 1984.

Naidu, A. S., Cooper, L. W., Finney, B. P., Macdonald, R. W., Alexander, C., and Semiletov, I. P.: Organic carbon isotope ratios $\left(\delta^{13} \mathrm{C}\right)$ of Arctic Amerasian continental shelf sediments, Int. J. Earth. Sci., 89, 522-532, 2000.

Nascimento, F. J. A., Karlson, A. M. L., and Elmgren, R.: Settling blooms of filamentous cyanobacteria as food for meifauna assemblages, Limnol. Oceanogr., 53, 2636-2643, 2008.

Nixon, S. W.: Coastal marine eutrophication: a definition, social causes, and future concerns, Ophelia, 41, 199-219, 1995.

Nixon, S. W., Oviatt, C. A., Frithsen, J., and Sullivan, B.: Nutrients and the productivity of estuarine and coastal marine ecosystems, J. Limnol. Soc. S. Afr., 12, 43-71, 1986.

Pearson, T. H. and Rosenberg, R.: Macrobenthic successions in relation to organic enrichment and pollution of the marine environment, Oceanogr. Mar. Biol.-Annu. Rev., 16, 229-311, 1978.

Parsons, T. R., Maita, Y., and Lalli, C. M.: A Manual of Chemical and Biological Methods for Seawater Analysis, Pergamon Press, New York, 1-184, 1984.

Peterson, B. J. and Howarth, R. W.: Sulfur, carbon, and nitrogen isotopes used to trace organic matter flow in the salt marsh estuaries of Sapelo Islan, Georgia, Limnol. Oceanogr., 32, 1195-1213, 1987.

20

Peterson, B. J., Howarth, R. W., and Garritt, R. H.: Multiple stable isotopes used to trace the flow of organic matter in estuarine food webs, Science, 227, 1361-1363, 1985.

Pihl, L.: Changes in the diet of demersal fish due to eutrophication-induced hypoxia in the Kattegat, Sweden, Can. J. Fish. Aquat. Sci., 51, 321-336, 1994.

25 Post, D. M.: Using stable isotopes to estimate trophic position: models, methods, and assumptions, Ecology, 83, 703-718, 2002.

Powers, S. P., Peterson, C. H., Christian, R. R., Sullivan, E., Powers, M. J., Bishop, M. J., and Buzzelli, C. P.: Effects of eutrophication on bottom habitat and prey resources of demersal fishes, Mar. Ecol. Prog. Ser., 302, 233-243, 2005.

so Raven, J. A., Johnston, A. M., Newman, J. R., and Scrim-Geour, C. M.: Inorganic carbon acquisition by aquatic photo-lithotrophs of the Dighty Bum, Angus, U.K.: uses and limi-tations of natural abundance measurements of carbon isotopes, New Phytol., 127, 271-286, 1994.

\section{BGD}

10, 1051-1081, 2013

\section{Riverborne inorganic and organic matters to the benthic food web}

N. N. Chang et al.

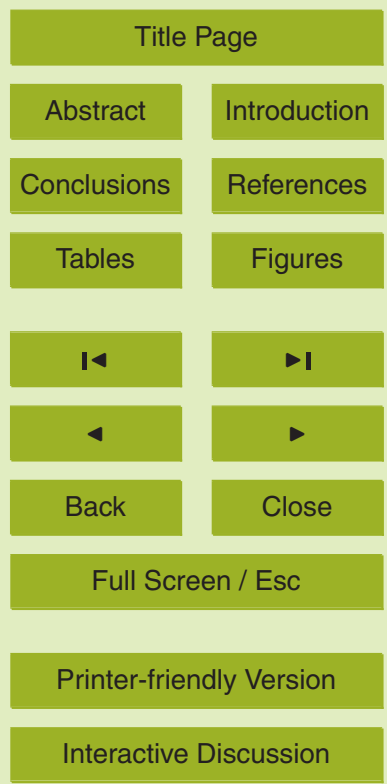


Riera, P. and Richard, P.: Isotopic determination of food sources of Crassostrea gigas along a trophic gradient in the estuarine bay of Marennes-Oléron, Estuar. Coast. Shelf Sci., 42, 347-360, 1996.

Savoye, N., Aminot, A., Tréguer, P., Fontugne, M., Naulet, N., and Kérouel, R.: Dynamics of particulate organic matter $\delta^{15} \mathrm{~N}$ and $\delta^{13} \mathrm{C}$ during spring phytoplankton blooms in a macrotidal ecosystem (Bay of Seine, France), Mar. Ecol. Prog. Ser. 255, 27-41, 2003.

Schindler, D. E., Carpenter, S. R., Cole, J. J., Kitchell, J. E., and Pace, M. L.: Influence of food web structure on carbon exchange between lakes and the atmosphere, Science, 277, 248-250, 1997.

10 Shan, X. J., Jin, X. S., and Yuan, W.: Fish assemblage structure in the hypoxic zone in the Changjiang (Yangtze River) estuary and its adjacent waters, Chin. J. Oceanol. Limnol., 28, 459-469, 2010.

Tan, F. C. and Stain, P. M.: Carbon isotope ratios of particulate organic matter in the Gulf of St. Lawrence, J. Fish. Res. Board Can., 36, 678-682, 1979.

15 Tang, D. L., Di, B. P., Wei, G. F., Ni, I. H., Oh, I. S., and Wang, S. F.: Spatial, seasonal and species variations of harmful algal blooms in the South Yellow Sea and East China Sea, Hydrobiologia, 568, 245-253, 2006.

Tamelander, T., Kivimae, C., Bellerby, R. G., Renaud, P. E., and Kristiansen, S.: Base-line variations in stable isotope values in an Arctic marine ecosystem: effects of carbon and nitrogen uptake by phytoplankton, Hydrobiologia, 630, 63-73, 2009.

Vadeboncoeur, Y. and Jeppesen, E.: From Greenland to green lakes: cultural eutrophication and the loss of benthic pathways in lakes, Limnol. Oceanogr., 48, 1408-1418, 2003.

Vadeboncoeur, Y., Jeppeson, E., Vanderz, A. M. J., Schierup, H., Chistoffersen, K., and Lodge, D. M.: Cultural eutrophication and the loss of benthic energy pathways in lakes, Limnol. Oceanogr., 48, 1408-1418, 2003.

Vob, M. and Struck, U.: Stable nitrogen and carbon isotopes as indicator of eutrophication of the Oder river (Baltic Sea), Mar. Chem., 59, 35-49, 1997.

Wang, B.: Cultural eutrophication in the Changjiang (Yangtze River) plume: history and perspective, Estuarine Coastal Shelf Sci., 69, 471-477, 2006.

30 Wang, J. and Wu, J.: Occurrence and potential risks of harmful algal blooms in the East China Sea, Sci. Total Environ., 407, 4012-4021, 2009.

Welschmeyer, N. A.: Fluorometric analysis of chlorophyll $a$ in the presence of chlorophyll $b$ and pheopigments, Limnol. Oceanogr., 39, 1985-1992, 1994.

1070

\section{BGD}

10, 1051-1081, 2013

\section{Riverborne inorganic and organic matters to the benthic food web}

N. N. Chang et al.

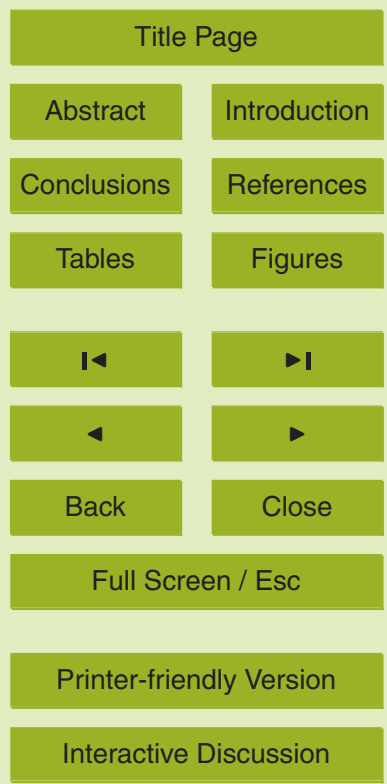


Wada, E., Mizutami, H., and Minagawa, M.: The use of stable isotopes for food web analysis, Crit. Rev. Food Sci. Nutr., 30, 361-371, 1991.

Wu, Y., Zhang, J., Li, D. J., Wei, H., and Lu, R. H.: Isotope variability of particulate organic matter at the PN section in the East China Sea, Biogeochemistry, 65, 31-49, 2003.

5 Wu, Y., Dittmar, T., Ludwichowski, K.-U., Kattner, G., Zhang, J., Zhu, Z. Y., and Koch, B. P.: Tracing suspended organic nitrogen from the Yangtze River catchment into the East China Sea, Mar. Chem., 107, 367-377, 2007.

Zhou, M. J., Shen, Z. L., and Yu, R. C.: Responses of a coastal phytoplankton community to increased nutrient input from the Changjiang (Yangtze) River, Cont. Shelf Res., 28, 14831489, 2008.

Zhu, C., Xue, B., Pan, J., Zhang, H., Wagner, T., and Pancost, R. D.: The dispersal of sedimentary terrestrial organic matter in the East China Sea (ECS) as revealed by biomarkers and hydro-chemical characteristics, Org. Geochem., 29, 952-957, 2008.

\section{BGD}

10, 1051-1081, 2013

\section{Riverborne inorganic and organic matters to the benthic food web}

N. N. Chang et al.

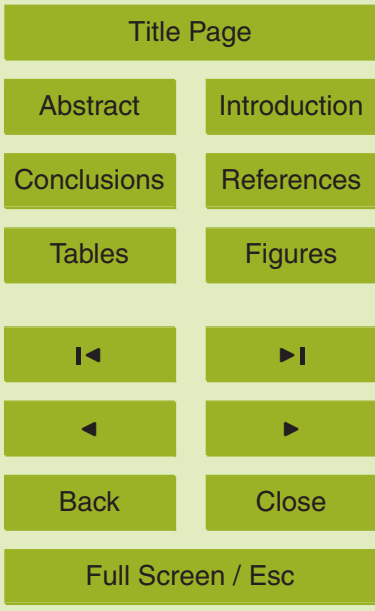

Printer-friendly Version

Interactive Discussion 


\section{BGD}

10, 1051-1081, 2013

Table 1. Distance from shore, bottom depth, temperature (Temp.), salinity (Sal.), dissolved inorganic nitrogen (DIN), and chlorophyll a (Chl) concentrations measured in the surface water $(<5 \mathrm{~m})$ of the East China Sea, by year and site $(\mathrm{Stn})$.

\begin{tabular}{llrrrrrr}
\hline Time & Stn & $\begin{array}{r}\text { Distance } \\
(\mathrm{km})\end{array}$ & $\begin{array}{r}\text { Depth } \\
(\mathrm{m})\end{array}$ & $\begin{array}{r}\text { Temp. } \\
\left({ }^{\circ} \mathrm{C}\right)\end{array}$ & $\begin{array}{r}\text { Sal. } \\
{[\mathrm{DIN}]} \\
(\mu \mathrm{M})\end{array}$ & $\begin{array}{r}{[\mathrm{Chl}]} \\
\left(\mathrm{mg} \mathrm{m}^{-3}\right)\end{array}$ \\
\hline Jul 2008 & A1 & 151.50 & 60 & 25.10 & 28.52 & 23.42 & 3.33 \\
& A2 & 273.40 & 60 & 27.41 & 33.28 & 1.57 & 0.13 \\
& A3 & 376.88 & 90 & 27.02 & 31.90 & 2.22 & 0.58 \\
& A4 & 465.25 & 102 & 28.81 & 32.63 & 1.44 & 0.14 \\
& B1 & 63.50 & 45 & 24.26 & 28.31 & 35.78 & 2.28 \\
\hline Jul 2009 & A1 & 151.50 & 59 & 24.76 & 32.10 & 4.17 & 1.82 \\
& A2 & 273.40 & 60 & 27.09 & 32.44 & 0.35 & 0.92 \\
& A3 & 376.88 & 89 & 27.09 & 32.47 & 0.31 & 0.43 \\
& A4 & 465.25 & 100 & 26.57 & 33.19 & 0.40 & 0.17 \\
& C1 & 48.26 & 29 & 23.74 & 33.53 & 8.38 & 2.30 \\
\hline \multirow{3}{*}{ Jul 2010 } & O1 & 77.37 & 26 & 24.43 & 19.33 & 40.28 & 1.99 \\
& A1 & 151.50 & 60 & 24.52 & 25.44 & 22.05 & 3.36 \\
& A2 & 273.40 & 59 & 26.23 & 29.50 & 6.64 & 2.55 \\
& A3 & 376.88 & 90 & 26.04 & 29.41 & 3.44 & 1.41 \\
& C1 & 48.26 & 32 & 25.34 & 24.80 & 27.10 & 4.67 \\
\hline
\end{tabular}

Riverborne inorganic and organic matters to the benthic food web

N. N. Chang et al.

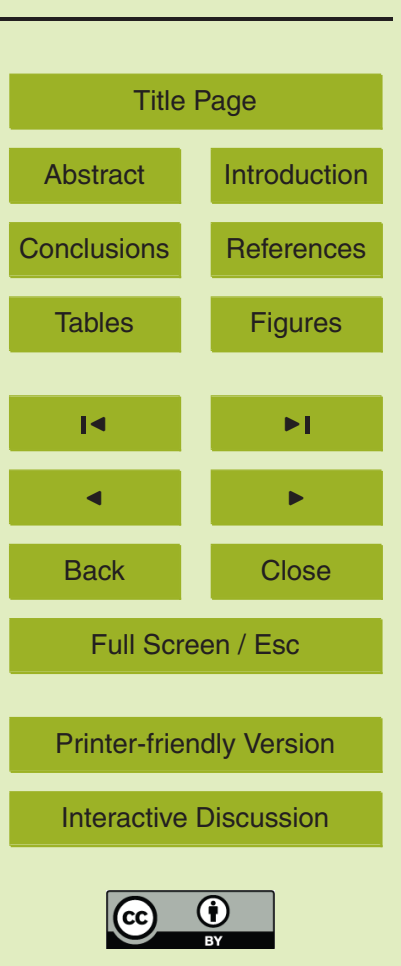




\section{BGD}

10, 1051-1081, 2013

Riverborne inorganic and organic matters to the benthic food web

Table 2. Stable isotope compositions $\left(\delta^{13} \mathrm{C}\right.$ and $\left.\delta^{15} \mathrm{~N}\right)$ and carbon to nitrogen ratio $(\mathrm{C} / \mathrm{N})$ of zooplankton samples from the East China Sea. Chl. a: concentrations of chlorophyll $a$ in the surface water $(<5 \mathrm{~m})$, by date and site $(\mathrm{Stn})$.

\begin{tabular}{llrrrrr}
\hline Time & Stn & Salinity & $\begin{array}{r}\mathrm{Chl} a \\
\left(\mathrm{mg} \mathrm{m}^{-3}\right)\end{array}$ & $\delta^{13} \mathrm{C}(\% \circ)$ & $\delta^{15} \mathrm{~N}(\% \circ)$ & $\mathrm{C} / \mathrm{N}$ \\
\hline Jul 2008 & O1 & 25.62 & 3.27 & -19.22 & 3.07 & 7.43 \\
Jul 2008 & ZOa & 32.29 & 0.15 & -21.37 & 5.56 & 6.89 \\
Jul 2009 & O1 & 23.80 & 2.47 & -21.31 & 2.76 & 8.42 \\
Jul 2009 & A4 & 33.19 & 0.17 & -21.79 & 5.26 & 6.88 \\
Jul 2010 & A1 & 25.44 & 2.87 & -19.96 & 3.42 & 5.75 \\
Jul 2010 & ZOb & 30.09 & 1.12 & -20.13 & 6.79 & 6.40 \\
\hline
\end{tabular}

Title Page

Abstract

Conclusions

Tables

14

4

Back

Full Screen / Esc

Printer-friendly Version

Interactive Discussion 


\section{BGD}

10, 1051-1081, 2013

Table 3. Kruskal-Wallis test and multiple comparisons among mean $\delta^{13} \mathrm{C}$ and $\delta^{15} \mathrm{~N}$ for crustacea and fish, from the East China Sea, by time and sampling site. $N=$ sample sizes.

\begin{tabular}{|c|c|c|c|c|c|c|c|c|c|c|c|c|c|}
\hline & \multirow[t]{2}{*}{ Time } & \multirow[t]{2}{*}{ Stn } & \multirow[t]{2}{*}{$N$} & \multirow[t]{2}{*}{ Species } & \multirow{2}{*}{$\begin{array}{c}\text { Total } \\
\text { df }\end{array}$} & \multicolumn{4}{|c|}{$\delta^{13} \mathrm{C}(\% \circ)$} & \multicolumn{4}{|c|}{$\delta^{13} \mathrm{~N}(\% \circ)$} \\
\hline & & & & & & Mean & SD & Chi-sq & $p$-value & Mean & SD & Chi-sq & $p$-value \\
\hline \multirow[t]{3}{*}{ Crustacean } & Jul 2008 & A1 & 27 & 12 & 50 & $-16.07^{\mathrm{a}}$ & 0.65 & 34.48 & $<0.0001$ & 10.60 & 0.79 & 0.1 & 0.95 \\
\hline & & $\mathrm{A} 2$ & 17 & 6 & & $-17.65^{\mathrm{b}}$ & 0.55 & & & 10.56 & 0.5 & & \\
\hline & & A3 & 7 & 4 & & $-17.87^{b}$ & 0.56 & & & 10.65 & 0.27 & & \\
\hline \multirow[t]{15}{*}{ Fish } & Jul 2008 & B1 & 14 & 5 & 164 & $-15.32^{\mathrm{a}}$ & 0.7 & 99.71 & $<0.0001$ & $10.76^{b}$ & 0.49 & 26.23 & $<0.0001$ \\
\hline & & $\mathrm{A} 1$ & 39 & 14 & & $-16.12^{\mathrm{a}}$ & 0.8 & & & $11.22^{\mathrm{ab}}$ & 0.91 & & \\
\hline & & $\mathrm{A} 2$ & 54 & 22 & & $-17.56^{b}$ & 0.55 & & & $11.29^{b}$ & 0.91 & & \\
\hline & & A3 & 34 & 17 & & $-17.50^{b}$ & 0.74 & & & $11.82^{\mathrm{a}}$ & 0.9 & & \\
\hline & & A4 & 24 & 11 & & $-18.23^{c}$ & 0.54 & & & $10.66^{b}$ & 0.94 & & \\
\hline & Jul 2009 & $\mathrm{C} 1$ & 11 & 3 & 77 & $-16.86^{a}$ & 0.7 & 22.7 & 0.0001 & $10.24^{b}$ & 0.87 & 26.8 & $<0.0001$ \\
\hline & & $\mathrm{A} 1$ & 25 & 8 & & $-17.17^{\mathrm{a}}$ & 0.55 & & & $10.65^{b}$ & 0.75 & & \\
\hline & & $\mathrm{A} 2$ & 18 & 6 & & $-17.51^{\mathrm{ab}}$ & 0.57 & & & $11.44^{\mathrm{a}}$ & 0.83 & & \\
\hline & & A3 & 14 & 6 & & $-17.75^{\mathrm{b}}$ & 0.39 & & & $11.73^{\mathrm{a}}$ & 0.5 & & \\
\hline & & A4 & 10 & 4 & & $-17.82^{b}$ & 0.36 & & & $11.20^{\mathrm{ab}}$ & 0.8 & & \\
\hline & Jul 2010 & O1 & 9 & 3 & 86 & $-15.93^{\mathrm{ac}}$ & 0.96 & 54.22 & $<0.0001$ & $8.76^{d}$ & 1.19 & 35.77 & $<0.0001$ \\
\hline & & $\mathrm{C} 1$ & 7 & 2 & & $-14.31^{a}$ & 0.44 & & & $9.48^{\mathrm{cd}}$ & 0.75 & & \\
\hline & & $\mathrm{A} 1$ & 29 & 10 & & $-15.38^{\mathrm{a}}$ & 0.84 & & & $10.61^{b c}$ & 0.61 & & \\
\hline & & $\mathrm{A} 2$ & 21 & 10 & & $-16.69^{b c}$ & 0.66 & & & $11.22^{\mathrm{a}}$ & 0.62 & & \\
\hline & & $\mathrm{A} 3$ & 21 & 7 & & $-17.48^{b}$ & 0.91 & & & $10.96^{\mathrm{ab}}$ & 0.62 & & \\
\hline
\end{tabular}

Different superscript letters indicate a significant difference among sites in a given year.

\section{Riverborne inorganic and organic matters to the benthic food web}

N. N. Chang et al.

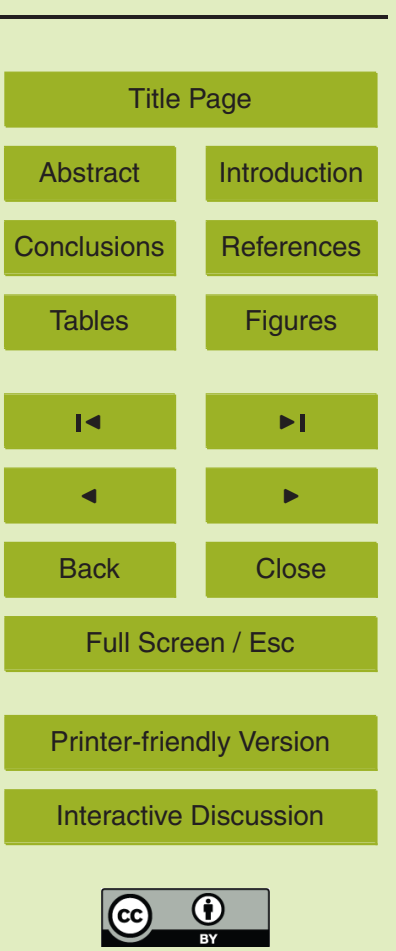




\section{BGD}

10, 1051-1081, 2013

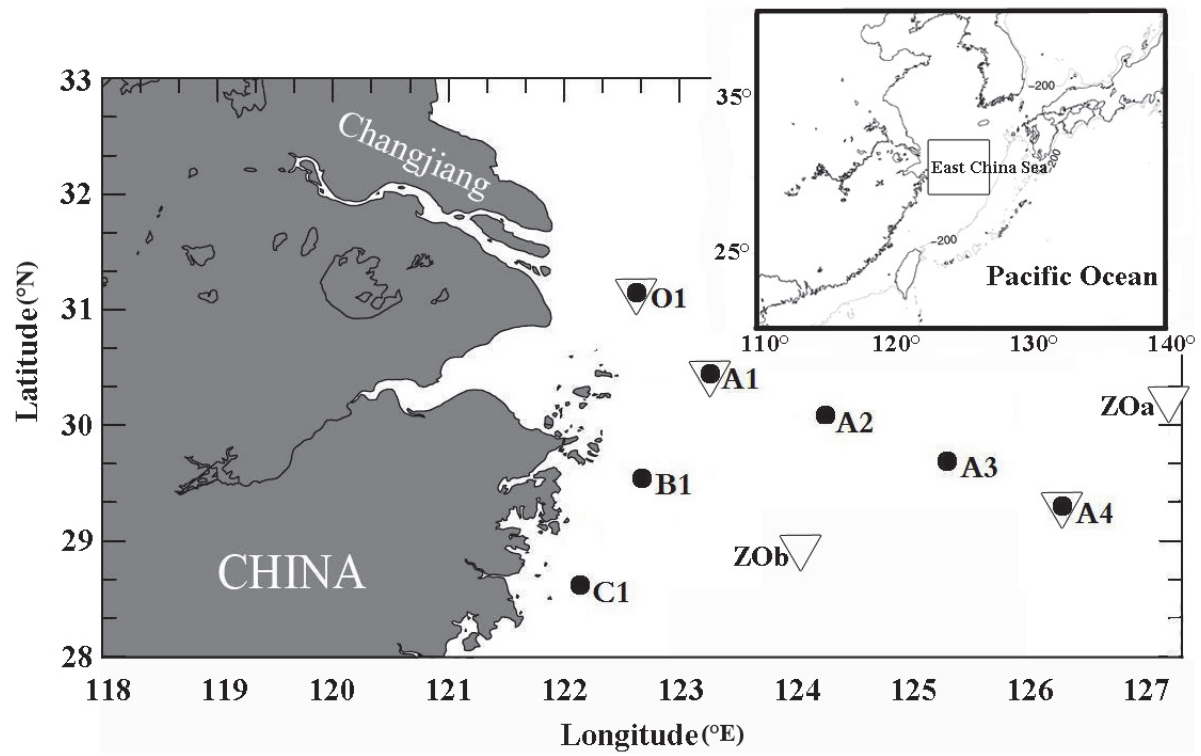

Riverborne inorganic and organic matters to the benthic food web

N. N. Chang et al.

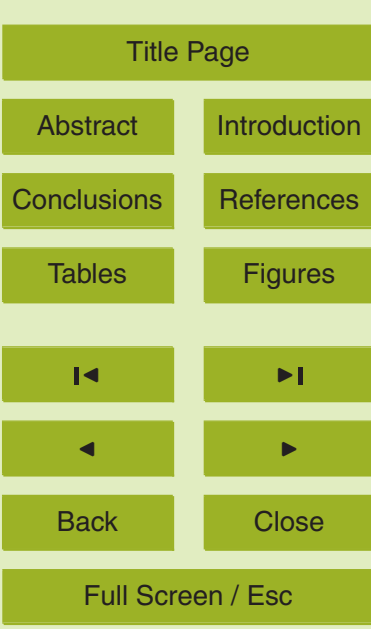

Printer-friendly Version

Interactive Discussion 


\section{BGD}

$10,1051-1081,2013$

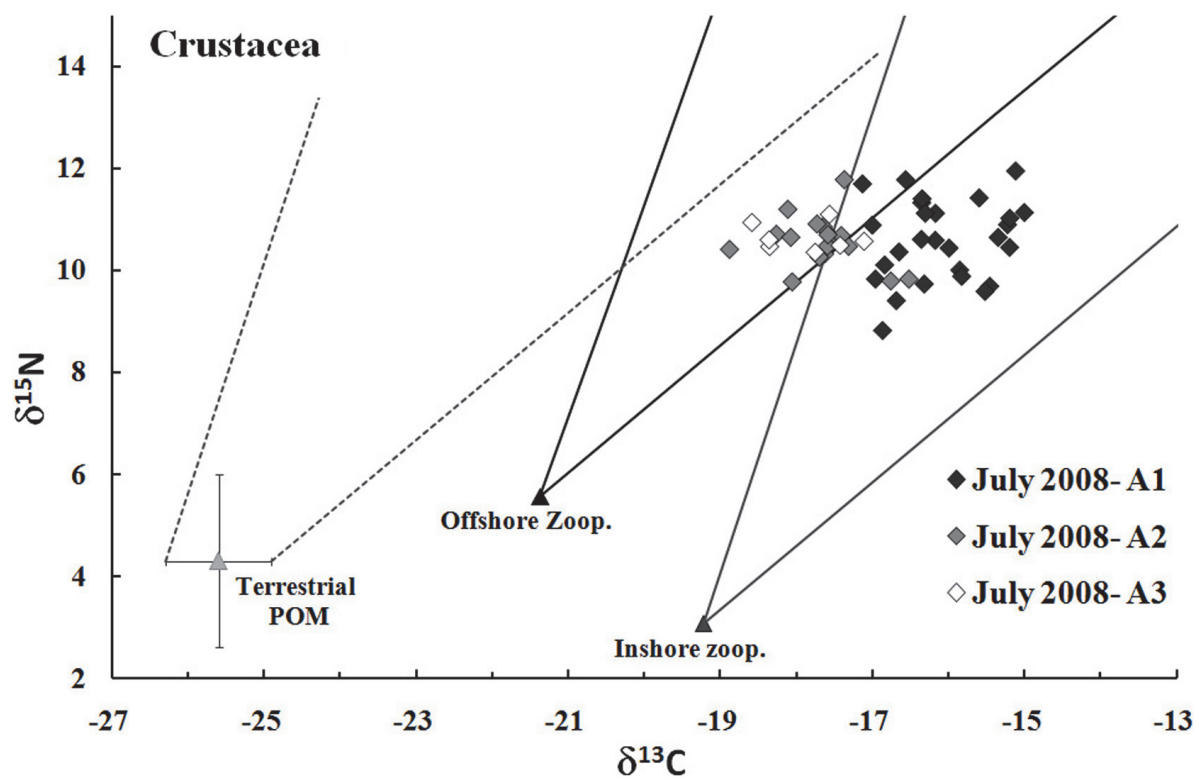

Fig. 2. $\delta^{13} \mathrm{C}$ and $\delta^{15} \mathrm{~N}$ biplot of crustacea collected from the East China Sea in July 2008. Funnel-shaped areas show the potential isotopic ranges of consumers that fed on inshore and offshore marine primary consumers (zooplankton) and terrestrial particulate organic matters (POM) (considering trophic enrichment of $+1 \%$ in $\delta^{13} \mathrm{C}$ and $+4.5 \%$ in $\delta^{15} \mathrm{~N}$ and of $+2 \%$ in $\delta^{13} \mathrm{C}$ and $+2.5 \%$ in $\left.\delta^{15} \mathrm{~N}\right)$.
Riverborne inorganic and organic matters to the benthic food web

N. N. Chang et al.

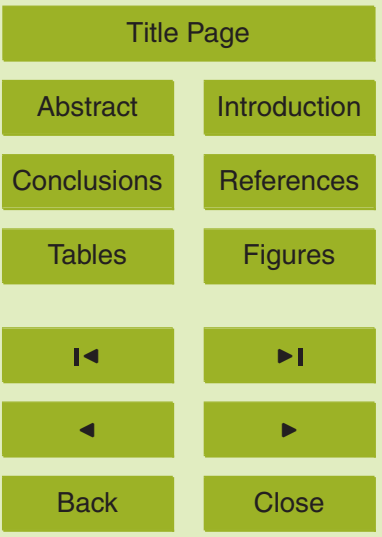

Full Screen / Esc

Printer-friendly Version

Interactive Discussion 


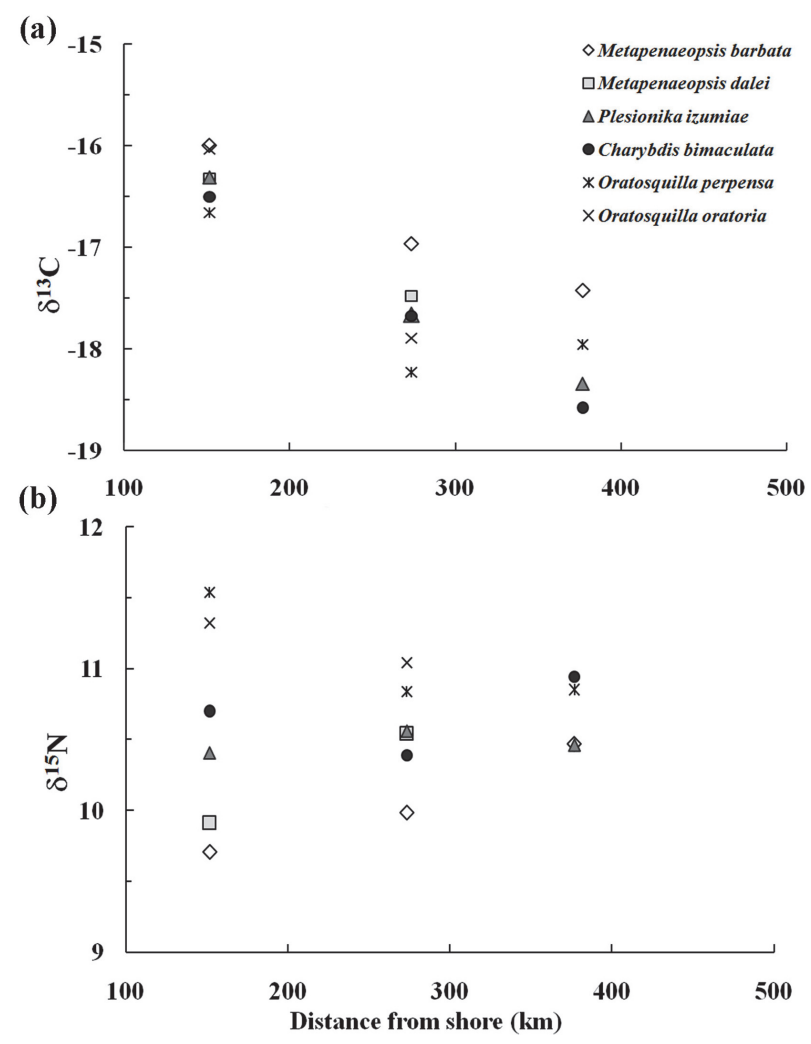

\section{BGD}

10, 1051-1081, 2013

Riverborne inorganic and organic matters to the benthic food web

N. N. Chang et al.

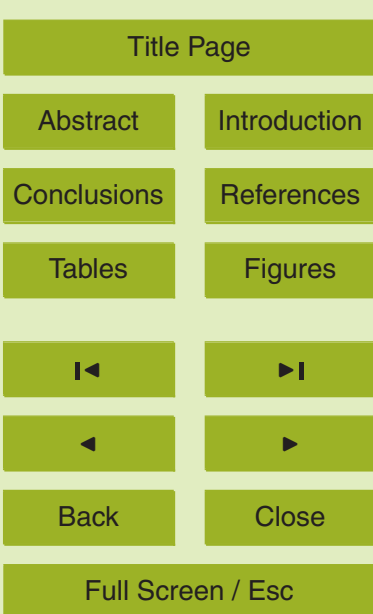

Fig. 3. (a) $\delta^{13} \mathrm{C}$ and (b) $\delta^{15} \mathrm{~N}$ values of crustacea from the East China Sea versus the distance from shore.

Printer-friendly Version

Interactive Discussion 


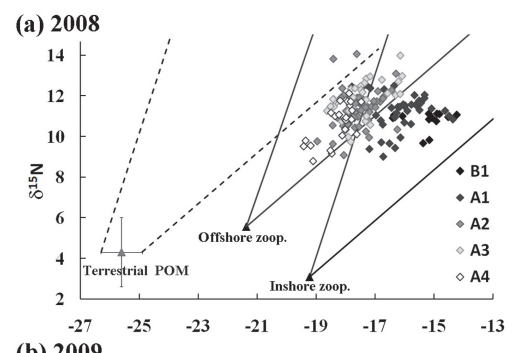

\section{BGD}

$10,1051-1081,2013$

\section{Riverborne inorganic and organic matters to the benthic food web}
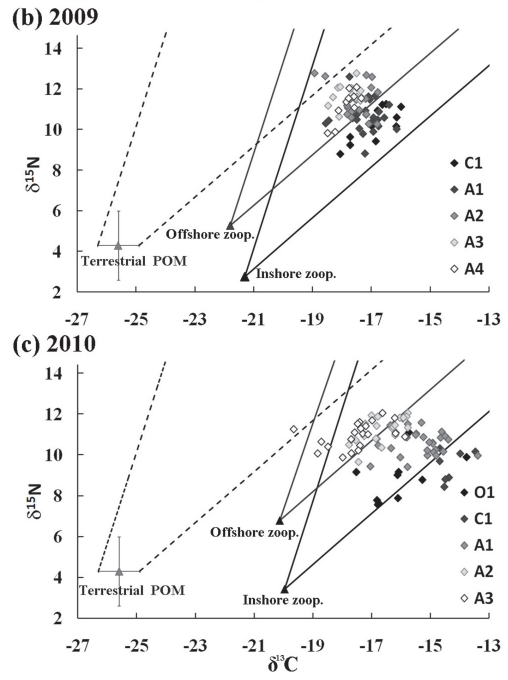

Fig. 4. $\delta^{13} \mathrm{C}$ and $\delta^{15} \mathrm{~N}$ biplot of demersal fish collected from the East China Sea in July of (a) 2008, (b) 2009 and (c) 2010. Funnel-shaped areas showing the potential isotopic composition ranges of consumers that fed on zooplankton (Zoop.) or terrestrial POM (considering trophic enrichment of $+1 \%$ in $\delta^{13} \mathrm{C}$ and $+4.5 \%$ in $\delta^{15} \mathrm{~N}$ and of $+2 \%$ o in $\delta^{13} \mathrm{C}$ and $+2.5 \%$ in $\delta^{15} \mathrm{~N}$ ). Each data point indicates the isotopic composition of one fish.

N. N. Chang et al.

Title Page

Abstract Introduction

Conclusions References

Tables

Figures

14

4

Back

\section{Full Screen / Esc}

Printer-friendly Version

Interactive Discussion 
BGD

10, 1051-1081, 2013
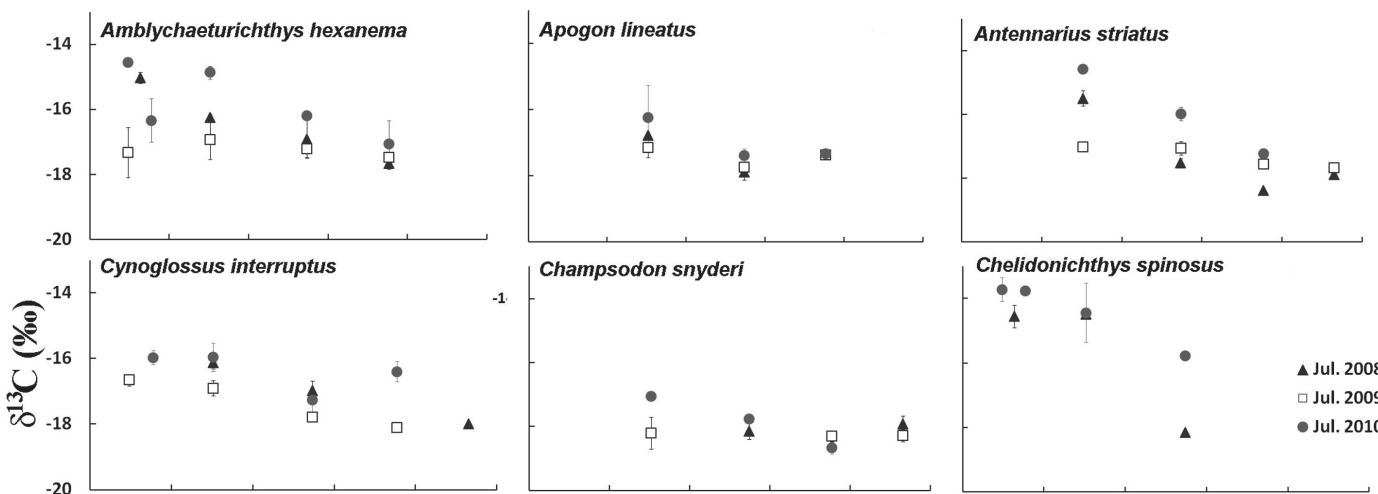

Champsodon snyderi
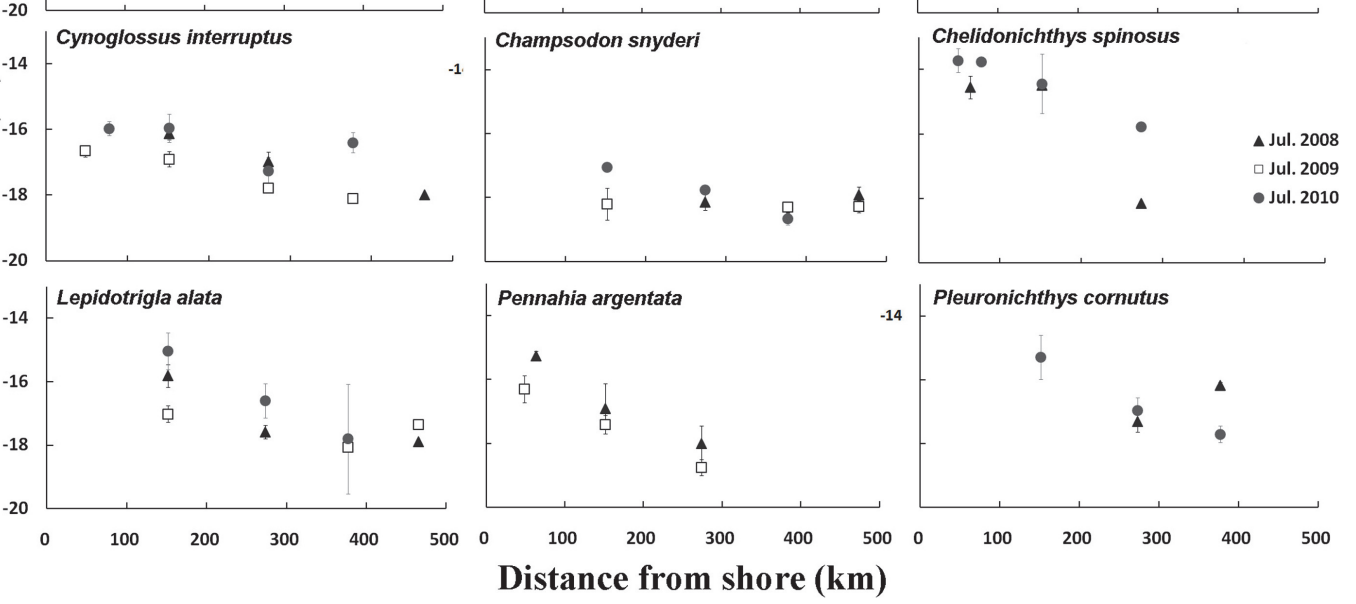

Fig. 5. Spatial and temporal variations in $\delta^{13} \mathrm{C}$ (mean $\pm \mathrm{SD}$ ) of nine common fish species from the East China Sea.

\section{Riverborne inorganic and organic matters to the benthic food web \\ N. N. Chang et al.}

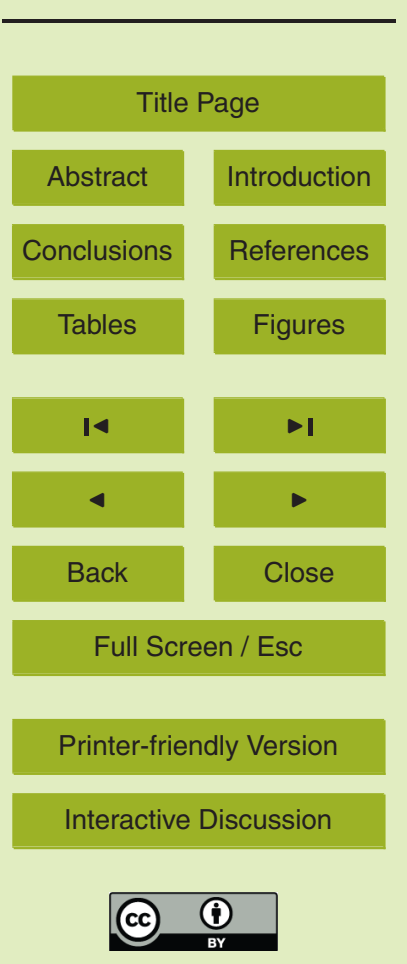


BGD

10, 1051-1081, 2013
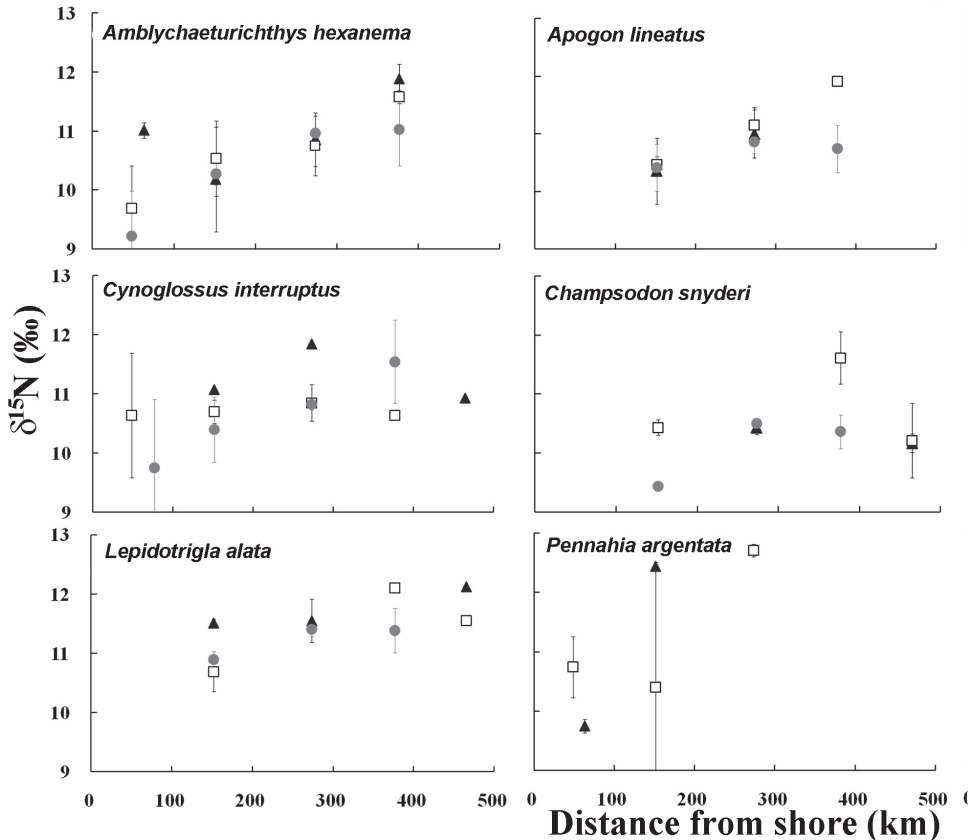

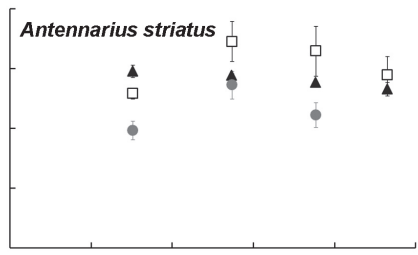

Chelidonichthys spinosus

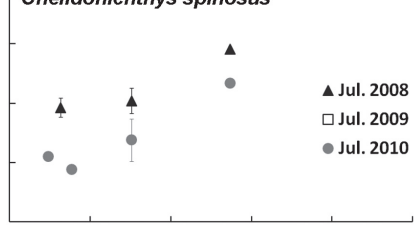

Pleuronichthys cornutus

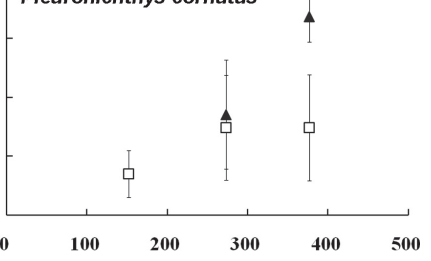

Fig. 6. Spatial and temporal variations in $\delta^{15} \mathrm{~N}($ mean $\pm \mathrm{SD})$ of nine common fish species from the East China Sea.
Riverborne inorganic and organic matters to the benthic food web

N. N. Chang et al.

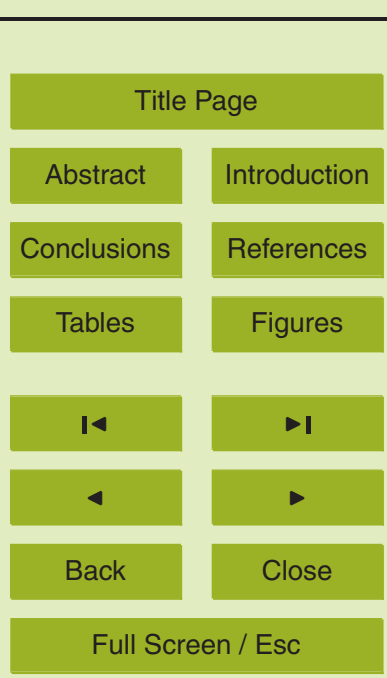

Printer-friendly Version

Interactive Discussion 


\section{BGD}

$10,1051-1081,2013$

(a) Chlorophyll $a$ and $\delta^{13} \mathrm{C}$

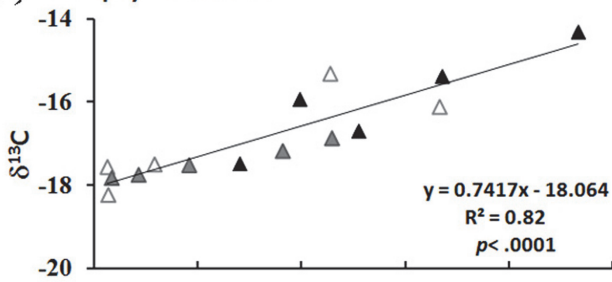

(c) Chlorophyll $a$ and $\delta^{15} \mathrm{~N}$

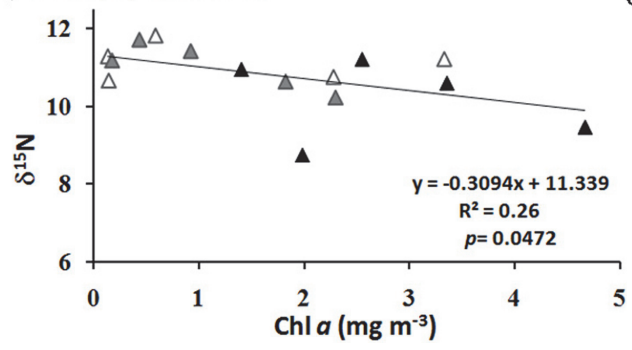

(b) DIN and $\delta^{13} \mathrm{C}$

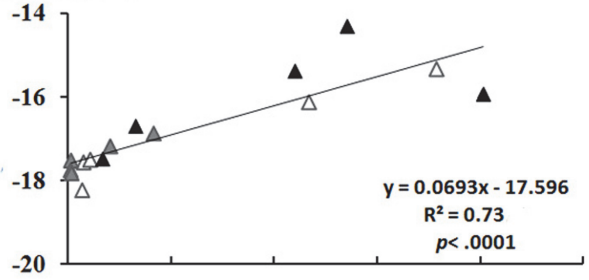

(d) DIN and $\delta^{15} \mathrm{~N}$

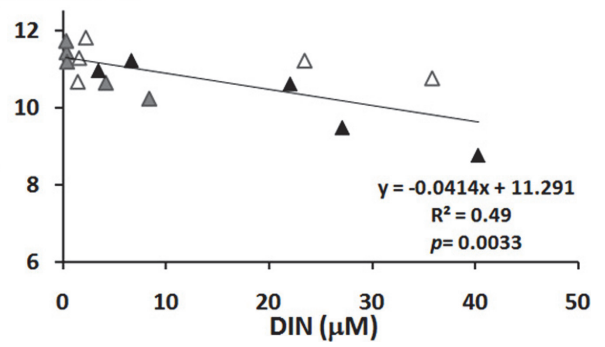

Fig. 7. Stable carbon and nitrogen isotope compositions of fish muscle from the East China Sea, by sampling site and date, plotted against concentrations of chlorophyll $a$ and dissolved inorganic nitrogen (DIN). White, grey and black triangles indicate the samplings in July 2008, 2009 and 2010, respectively. Solid lines are simple linear regressions with equation, $r^{2}$ and $p$-values.

\section{Riverborne inorganic and organic matters to the benthic food web \\ N. N. Chang et al.}

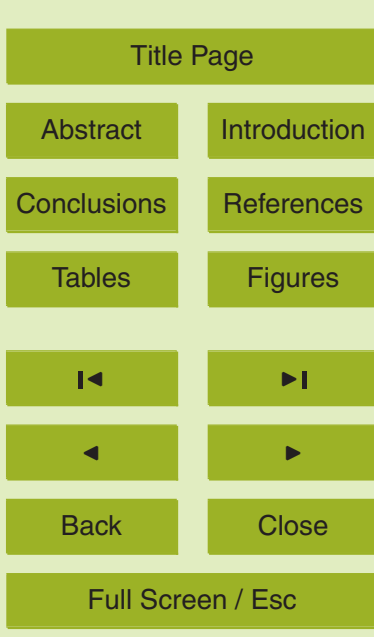

Printer-friendly Version

Interactive Discussion 